\title{
Los viajeros mexicanos del siglo XIX y sus musulmanes*
}

\author{
Adrián Tolentino García**
}

Recibido el 29 de enero de 2019; aceptado el 17 de mayo de 2019

\section{RESUMEN}

Este escrito estudia los viajeros mexicanos que visitaron el Medio Oriente durante el siglo XIX. Se analizará cómo es que estos mexicanos interpretaron a los musulmanes y el Islam con que inevitablemente se cruzaron durante cada viaje. Se busca explicar por qué los mexicanos interpretaron el Islam de una forma determinada. Para lograrlo, se retoma el tránsito de la herencia hispánica de México a la Modernidad republicana. Este análisis presenta, así, las diferencias de cada acto de viajar, e indaga en la peculiaridad que modifica las impresiones que se vierten sobre los musulmanes.

Palabras clave: Imperio Otomano, Tierra Santa, peregrinación, itinerarios, relatos de viaje.

\section{Nineteenth century mexican travelers and their muslims}

\section{Abstract}

This research studies the Mexicans who traveled to the Middle East throughout the nineteenth century. An analysis will be made concerning the interpretations these travelers produced on the Muslims and the Islam they came across within each journey. This text explains why Mexicans interpret-

* Extiendo mis insuficientes agradecimientos por sus consejos, su lectura crítica y su tiempo a la doctora María Luisa Aspe, al maestro Tarik Zeraoui, y al doctor Armando Azúa. Aclaro aquí que las citas de estudios que no estén en español fueron traducciones mías. Dedico este escrito a María José Mancera.

** Universidad Iberoamericana, Ciudad de México, México. Correo electrónico: adtolentino@outlook.com. ORCID: https://orcid.org/0000-0002-6271-9040. 
ed Islam as they did. In order to attain such an explanation, an overview of the passage from the Hispanic heritage of Mexico to the Republican Modernity is carried out. Hence, this investigation presents the differences implied within each specific act of traveling, and inquires into the peculiarity that modifies every impression drawn regarding the Muslims.

Key words: Ottoman Empire, Holy Land, pilgrimage, itineraries, journey logs.

Si se quiere una expresión paradójica hela aquí: la verdad del viajero es su error. José Ortega y Gasset ${ }^{1}$

Cada nación se mofa de las demás, y todas tienen razón. Arthur Schopenhauer ${ }^{2}$

El concepto general de "Humanidad" se convierte en el contraconcepto de los conceptos particulares que le son inherentes.

Reinhart Koselleck ${ }^{3}$

\section{INTRODUCCIÓN}

$\square^{1}$ historiador y el lector de historia son dos actores que, irremediable工mente, irrumpen en el pasado. Trastocan, ambos, su curso pretérito y el norte que otrora seguía adquiere un flujo más familiar. El historiador, a golpe de preguntas vigentes, empuja los vectores del pasado hacia él. El lector de historia, por su parte, cae en dicho producto, por intereses, deseos o perplejidades que nacen cuando absorbe su circunstancia. El escrito de historia se convierte en el punto de fuga en que convergen los dos actores. Por eso, el pasado narrado y leído tiene que ver, más bien, con el presente que con un "tiempo perdido".

Este escrito, que inquiere los viajes y los viajeros, procede de una circunstancia fecunda en viajes y viajeros. A una persona del siglo XXI le es

Ortega y Gasset, El Espectador, Tomo VI (1930), p. 640.

Schopenhauer, Aphorismen zur Lebensweinsheit, p. 67.

Koselleck, Vergangene Zukunft. Zur Semantik geschichtlicher Zeiten, p. 249. Me basé fundamentalmente en el original para traducir la frase, aunque el texto consultado — citado más adelante—- fue la traducción en inglés. 
usado conversar de viajes, próximos o lejanos, como le es normal hablar de extranjeros, hábitos forasteros y monumentos del "patrimonio mundial". Es aun motivo de vanagloria el acto de viajar. Hoy, más que nunca, ese narcisismo fotográfico - que no paramos de ojear- sirve como un componente sine qua non del viaje.

$\mathrm{Y}$, aunque el viaje sea sólo posibilidad de unos cuantos, en el imaginario de los menos aventajados — como les llamaría Rawls—, también rezuma la fruición por el viaje. En acto, el viaje es largo y agobiante para las poblaciones con carencia consuetudinaria. El viaje es eso que pesarosamente realizan para llegar al área laboral de las urbes sobrepobladas. Áreas que, como se sabe, están geográficamente distantes de las áreas donde estas poblaciones pueden habitar. ${ }^{4}$ En potencia, por otro lado, el viaje es eso a lo que se había aspirado cuando llegan las vacaciones, es eso que merece un financiamiento que el salario no puede alcanzar en el corto plazo, cuya realización conlleva préstamos interminables.

Nuestra circunstancia ha democratizado los viajes. Se buscará objetarme diciendo que los viajes siempre han estado presentes en el imaginario colectivo, y que la corriente tesitura no diverge de las del pasado. ${ }^{5}$ Sin embargo, la ampliación, la vulgarización, la socialización —o como quiera llamársele- del acto de viajar es el fenómeno sui generis frente a las épocas antecedentes. En el imaginario colectivo ya está establecido el viaje y, además, ocupa un sitio privilegiado. Se comparte el deseo de viajar, sin importar la clase socioeconómica, y esto es signo irrevocable de que creemos en la posibilidad de cumplir el deseo.

Los investigadores que tocan el tema viajero en México repiten, casi robóticamente, lo que, a propósito, sentenció Ignacio Manuel Altamirano: "los mexicanos viajan poco". Nadie puede disputar que su reproche insinúa la exclusividad del acto de viajar en su época, y, por repercusión, la ausencia de este deseo en la colectividad. ${ }^{6}$ Nuestra circunstancia diverge transversalmente. Hoy, someramente dicho, lo que alguna vez se antojó imposible es posible. Y no está de sobra decir que lo que deviene posible desencadena una insólita serie de posibilidades.

4 Cfr. Vgr. Aguilar (coord.), Las grandes aglomeraciones y su periferia regional. Experiencias en Latinoamérica y España, México, p. 6; Soto y Padilla (coords.), Memoria del Congreso Nacional de Vivienda 2013. 12, 13 y 14 de marzo. Eje Temático 9: Desarrollo urbano y grandes conjuntos habitacionales, p. 14; por hablar, tan sólo, de la realidad mexicana.

5 Un documento referencial lee: "El viaje es uno de los temas recurrentes en la literatura universal; está presente ya en libros como la Biblia, la Odisea o el Corán” (Biblioteca Nacional de España, Libros de viajes y viajeros de los siglos XVI-XIX, p. 2, disponible en <http://www.bne.es/es/Micrositios/Guias/Viajes/resources/docs/Guia_Libros_de_de_viaje_ y_viajeros_Siglos_XVI-XIX.pdf $>$ ).

$6 \quad$ El dictum de Altamirano procede de Malanco, Viaje á Oriente, Libro I, p. xi. 
Una de estas nuevas posibilidades, nacida de esta rutina de viajes y viajeros, es la que incide en la comprensión que tenemos del pasado. Basta con una observación panorámica de las producciones historiográficas para notar la creciente recurrencia del tema viajero. Los coetáneos, historiógrafos del siglo XXI, comparten un gusto por las investigaciones de los viajes. No sólo eso: se ha incurrido en el acto de leer el pasado a través de la lente viajera. Es decir, el historiógrafo veintiunesco se aproxima a los sucesos del pasado con una hipótesis predispuesta a encontrar viajes y viajeros en donde antes no los había. ${ }^{7}$

Sirva un ejemplo ilustrativo: Martín Lutero ya no sólo es el reformador contestatario. Al profesor Russel Lemmons le fue dado mirar a un Lutero diferente. Tituló su ensayo: "Martín Lutero como viajero y traductor". ${ }^{8}$ Nos dice el profesor de la Universidad Estatal de Jacksonville: "Mientras que los estudiosos han apreciado, por mucho tiempo, la importancia de la traducción que Lutero hizo de la Biblia, [...] sus experiencias como viajero y el impacto de este hecho en su labor de traducción han sido enormemente ignorados". ${ }^{9}$ Procede a analizar, entonces, a ese Lutero que, por su condición viajera, pudo traducir la Biblia. Averígüese cómo reaccionarían los historiadores del pasado ante pareja personificación. Hoy —lo reitero—, cuando menos, seduce.

\section{Circunstancias disonanTES}

Está claro, entonces, que nuestra circunstancia ha visibilizado el viaje histórico, y a ello responde que los lectores actuales crean tener familiaridad con los relatos viajeros que nos llegan del pasado. Sin embargo, al paso que se nos abre la posibilidad de mirar nuevas aristas en la historia, corremos el riesgo de mirarlas con descuido. Corremos el riesgo, en suma, de ver nuestro propio reflejo en lugar de ver a través del cristal. Hay que poner distancia entre nuestra circunstancia y la del pasado. Todo lo que provenga del pasado tiene que sernos diferente hasta que se demuestre lo contrario.

Nuestra afinidad nos despoja de la habilidad de notar la distancia interpuesta entre nuestros actos de viajar y los pretéritos actos de viajar. No obstante la incapacidad, podemos valernos de un corriente parámetro con el que, altivamente, infravaloramos los tiempos anteriores en beneficio de nuestros tiempos: la técnica. Sabemos que los medios de transporte han "mejorado"

7 No vendría al caso mentar exhaustivamente producciones historiográficas sobre viajeros y viajes; sería, de suyo, insuficiente. Remítase al documento citado en la nota 6, cfr. supra.

8 Cfr. Lemmons, “'If there is a hell, then Rome stands upon it': Martin Luther as Traveler and Translator”, pp. 33-44.

9 Ibíd., p. 34. 
cuando comparamos nuestros aviones con los vapores y los ferrocarriles. La inmediatez con la que observamos los trayectos, hoy, frente a la de los trayectos en el siglo XIX es de una asimetría por sí sola evidente. Y, sin embargo, para el individuo decimonónico, viaje implicaba efectiva inmediatez.

Son múltiples las alabanzas que leemos, en los relatos viajeros, a los méritos del progreso cuando suben al vagón ferroviario. Dice uno de los viajeros con quien trataremos en este estudio: "Hoy que la distancia está por el vapor ya vencida, y que la ciencia ha destruido la barrera de viejas preocupaciones que mantenian incomunicados á los pueblos, los viajes por mar y tierra son partidas de recreo, $\mathrm{y}$ en el transcurso de noventa dias puede darse la vuelta al globo terrestre". ${ }^{10}$

Nuestra inmediatez y la de los decimonónicos no son una y la misma. Mientras que la rapidez del viaje aéreo exige casi, casi simultaneidad, la rapidez del viaje en vapor da cabida a la espera. En el avión hay un derroche de las expectativas en torno a nuestro destino, en tanto que en el vapor hay una frugalidad, incluso, estratégica de esas expectativas. Es decir, no tenemos suficiente tiempo para estudiar nuestros propios deseos ni las posibilidades que mentalmente se nos abren cuando pensamos en el lugar al que llegaremos. A diferencia nuestra, hay semanas de por medio para que el viajero decimonónico se relacione con sus expectativas de viaje, y eso ¡durante el mismísimo acto de viajar! Tanto es así que pueden redactarlas y re redactarlas cuantas veces necesiten en sus indispensables diarios.

Este ensanchamiento temporal también se manifiesta en lo espacial. Un pasajero de aerolínea, aun el más acomodado, no puede aspirar a recorrer largos pasillos con diferentes salones, sentarse al comedor, salir a recibir la brisa, forjar amistades en cuestión de días con cinco o más viajeros, como sí lo hacían los huéspedes del vapor. Nadie desafiaría al sentido común al denominar como huésped al tripulante del aeroplano, pues no existe la prerrogativa del camarote. El cuerpo es prisionero de la comodidad en nuestros traslados inmediatos.

En ese siglo XIX, entre la partida y la llegada mediaba un momento crucial. La dosificación de las expectativas derivaba en la formación de imágenes y de categorías sobre lo desconocido. Es crucial, decía, porque los viajeros participarán de las fuentes de conocimiento que a la mano tengan, durante la navegación, para saber qué les deparará.

Tienen, para empezar, compañía forastera y pueden, si no padecen de trato adusto, inaugurar charlas para ablandar la curiosidad. Lo mismo que la conversación, existe otro medio para conocer el destino que se avecina.

10 López-Portillo y Rojas, Egipto y Palestina: apuntes de un viaje. Libro I: Egipto, p. 6. El resaltado es mío. 
Estos viajeros se reputan como gente civilizada. En el espeso listado de hábitos que todo hombre civilizado ostenta está, todos lo saben, el cultivo de sí mismo mediante lecturas asiduas. ${ }^{11}$ Por eso, no es difícil imaginar a estos viajeros en posesión de dos o tres impresos al interior de sus pesadas valijas. Francisco Bulnes, uno más de nuestros viajeros, confiesa: "[desde] el momento en que me ví en marcha, todos los fantasmas de mis lecturas se inclinaron bruscamente para presentarme el globo en sus expléndidos contrastes. Yo aproveché esta protección expontánea de la memoria, para poder apreciar á su hora el desarrollo de la realidad”. ${ }^{12}$ El libro es el depósito de la confianza de un viajero que tiene enfrente la calamidad de lo desconocido.

¿Qué leían los viajeros mexicanos que arribarían al —como le llamamos hoy- Medio Oriente? El destino que ilusiona a los viajeros mexicanos es, por lo general, la añoradísima Tierra Santa. Por lo menos, tres de estos aventureros nos dan noticia de haber digerido las líneas de un autor en común: el fraile seráfico Liévin de Hamme. ${ }^{13}$ En los tres pesados volúmenes del Guíaindicador de santuarios y lugares históricos en Tierra Santa, el franciscano belga ofrece información pragmática: todo redunda en el mejor provecho del peregrino.

El lector, agradecido por la erudición de este guía espiritual, encuentra cifras de precios y de distancias, fatigosas descripciones de toda menudencia con que se cruzará el viajero, y consejos de cómo comportarse. ${ }^{14}$ Visitando la Mezquita de Al-Aqsa, López-Portillo aprendió que ahí reposaban las sillas de Buraq (الئراق), el caballo que elevó al Profeta a los cielos. Perplejo, le intima a su lector:

11 Elias matiza varias diferencias entre "cultura” y "civilización”. Comienza su disquisición, sin embargo, diciendo que la "palabra 'cultivado' es muy próxima al concepto occidental de civilización y, en cierto modo, representa la forma más elevada del 'ser civilizado'” (Elias, El proceso de la civilización. Investigaciones sociogenéticas y psicogenéticas, p. 58).

12 Bulnes, Sobre el Hemisferio Norte. Once mil leguas. Impresiones de viaje a Cuba, los Estados Unidos, el Japon, China, Cochinchina, Egipto y Europa, p. 16.

13 Un viajero colombiano conoció al "Hermano Lievin de Hamme, belga de nacimiento", y dice de él que es "un hombre eminente en la historia de la geografía y arqueología de la Palestina" (Cuesta, Viaje a la Tierra Santa en el Año del Señor de 1870. Nueva edición de sus cartas, p. 43). La obra se publicó en 1869. José López-Portillo y Rojas compró el Guía en el puerto de Jaffa, y, a juzgar por cómo llama al autor — fra Lavinio-, se trata de la edición italiana (cfr. López-Portillo y Rojas, op. cit., Libro II: Palestina, p. 12). Pareja edición es la que, también, insinúa el ministro de la Legación mexicana en Roma, Luis Malanco (cfr. Malanco, Tomo Primero, op. cit., p. 495). Sólo el presbítero Trinidad Basurto parece haberlo leído en su idioma original (cfr. Basurto, Recuerdo de mi viaje. Historia de la segunda peregrinacion mejicana a Roma y primera a Tierra Santa, p. 189).

${ }_{14}$ Cfr. De Hamme, Guide-indicateur des sanctuaires et lieux historiques de la Terre-Sainte, Revue, augmentée et accompagnée de cartes, de plans et de vues. Première Partie. 


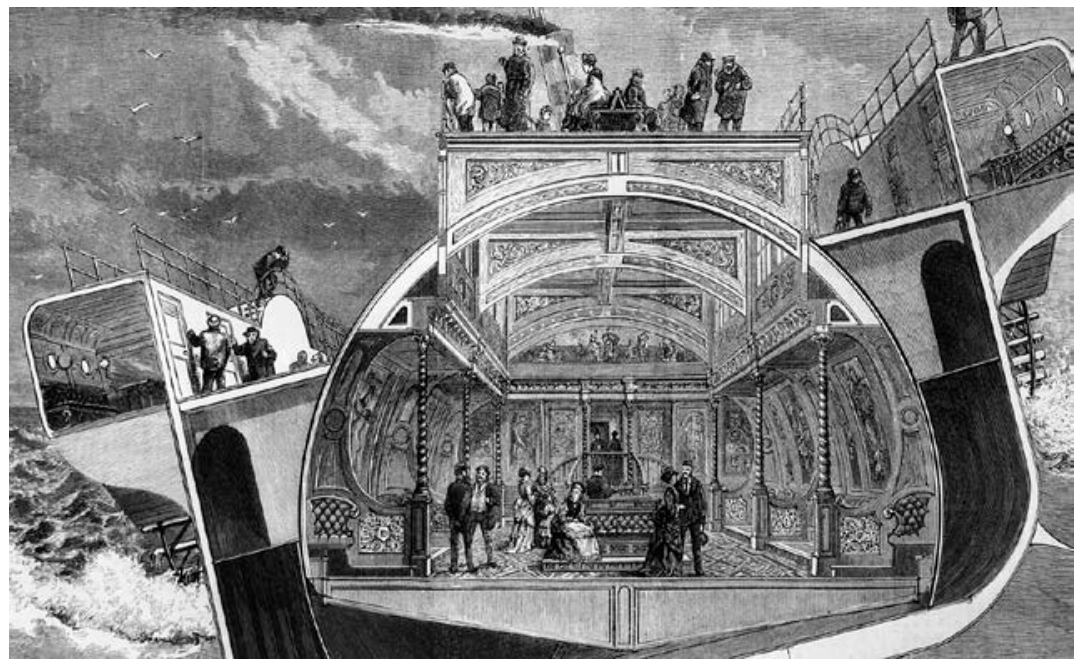

Imagen 1. La dificultad que todo viajero reprochaba insaciablemente era la enfermedad del mar: el mareo. Hubo innumerables quebraderos de cabeza para desterrar las náuseas durante el viaje. El ingeniero británico, Sir Henry Bessemer, diseñó un vapor cuyos salones y pasillos se balanceaban al ritmo de las ondulaciones para lograr una estabilización. Sin movimientos veleidosos, los viajeros podrían realizar cualquier acción con naturalidad, inclusive leer. El SS Bessemer sólo fue la suma de una buena intención y dos colisiones. (Grabado en madera de J. R. Brown (1874), reproducido de The Graphic: An Illustrated Weekly Newspaper, Dec. 12, 1874, p. 572).

Me pareció que semejante aserto era una broma, iba a reir cuando recordé la recomendacion que lei en el libro del hermano Lavinio: es, á saber, la de no hacer burla ni de lo que parezca el mayor absurdo en aquel sitio, pues todas estas majaderias son puntos de fe para los mahometanos, y cuando un creyente mira burlada su fe, se ciega y es feroz. ${ }^{15}$

Otros viajeros echan mano de diferentes géneros de impresos. Con su característico acento de ironía, Francisco Bulnes tácitamente nos enseña sus libros durante la aburrida travesía: 
Yo me entretuve en leer y examinar las facultades destructivas del pulpo que aparecia diariamente en mi plato. De mis ocupaciones inofensivas no saqué mas provecho que descubrir que tanto el pulpo de "Los trabajadores del mar," como el cañon en libertad de $93,{ }^{16}$ dan prueba de los granos de clemencia que posee a veces la imaginacion de Víctor Hugo. ${ }^{17}$

El General Ignacio Martínez, con el humilde deseo de conocer el mundo entero, se decidió “á tomar lecciones de inglés, á consultar mapas, á leer tratados de geografía y los viajes de Humboldt, Arago, Chateaubriand, Lamartin [sic], Burton, etc”. ${ }^{18}$ López-Portillo empalma largos versos, también, de Lamartine, para sublimar la belleza de las noches napolitanas. ${ }^{19}$ No faltan, tampoco, los impresos hojeados de plumas paisanas. Algunos viajeros exhiben un fino aprecio por el primer relato viajero al Medio Oriente, la Breve y sencilla narracion del viage del padre Guzmán, ${ }^{20} \mathrm{y}$, también, exhiben la emotividad que les inspiró Manuel Carpio con sus poesías religiosas. ${ }^{21}$ Otros agradecen la tropicalización que de las obras francesas realizó Mariano Galván Rivera, en los tres volúmenes de La Tierra Santa. ${ }^{22}$

Se asoma un tentativo contraste en este repaso de los impresos de los que se sirvieron los viajeros. Me refiero al contraste entre aquéllos que viajan en condición de peregrinación y los que viajan por motivos más mundanos. El peregrino, ejercitador del espíritu por antonomasia, entiende su viaje a la usanza piadosa. Y se acercará, entonces, a escritos que le faciliten una experiencia anagógica. El viajero lego tiene, por otro lado, intereses más “culturales”.

Estas tendencias divergentes de lectura me obligan a atender la siguiente reflexión: el viajero, en realidad, no cae sumido en lo desconocido cuando

16

referencia procede del capítulo IV, del Segundo Libro, de Noventa y Tres, en que Ví Hugo narra el cómo un cañón se destrinca durante la navegación. Metaforiza el funesto hecho como una "bestia sobrenatural". La referencia a Los Trabajadores del Mar es bien conocida (cfr. Hugo, Quatrevingt-treize, pp. 47-48).

17 Bulnes, op. cit., pp. 20-21 (subrayado del original).

18 Martínez, Viaje Universal. Visita a las cinco partes del mundo. Acompañado de un Mapa Ilustrativo y con un prólogo del distinguido literato General Vicente Riva Palacio, p. 9.

19 Cfr. López-Portillo y Rojas, Libro I, op. cit., p. 17. Se trata de la elegía X de las Armonías: Lamartine, Harmonies poétiques et religieuses, p. 274.

20 Como lo dice Luis Malanco: "Los viajes á Oriente eran un sueño, y de sólo leer las pocas hojitas del P. Guzmán [...] se helaba el entusiasmo religioso con el desaliento que causaba la distancia” (Malanco, Libro Primero, op. cit., p. xxi).

21 Varios de los viajeros copian los versos que escribió Carpio. Su biógrafo confirma que: "los viajeros de Tierra Santa lo ocuparon siempre mucho" (Couto, "Biografía de Don Manuel Carpio”, p. xv).

22 Galván, La tierra santa ó descripción exacta de Joppe, Nazareth, Belem, el Monte de los Olivos, Jerusalén y otros lugares célebres en el evangelio, a lo que se agregan una noticia sobre otros sitios notables del pueblo hebreo, 1842 (con esta ficha condenso los tres tomos). 
pisa el suelo extranjero. Por el contrario, el viajero entra al destino confiado en que ya lo conoce. Ése es el efecto inmediato de la lectura realizada en ese dilatadísimo punto medio entre la partida y la llegada. Según qué se lea y qué se oiga, nacerá el mundo a visitar. Despuntan, entonces, las peculiaridades de los impresos. Unos echan mano de plegarias y hagiografías, otros se sirven de versos y monografías. Con esta reflexión preliminar nos acercamos a dos géneros de viajeros, que de maneras disonantes realizan el viaje.

La distinción entre peregrino y viajero profano (o turista) resulta crucial. El Medio Oriente tuvo dos significados disonantes para los dos géneros de viajeros mexicanos. Para el primero, dicho territorio se trataba de la Tierra Santa, y era un espacio de penitencia, de encuentro con Dios. Para el viajero profano, el Medio Oriente era un espacio de recreación ("recreo", le llaman los decimonónicos), es turismo en ciernes, y la región no era conocida por ellos como la Tierra Santa, sino como el Oriente.

Es importante poner de relieve que los primeros mexicanos que visitaron el Medio Oriente fueron, precisamente, peregrinos. Ellos tienen una cosmovisión todavía hispánica, herencia del virreinato que acababa, apenas, de dar lugar a una inestable nación independiente. ${ }^{23} \mathrm{El}$ baluarte de los primeros mexicanos — se sabe de sobra - era la religión católica, que configuraba incluso la Constitución y aun el pensamiento de numerosos liberales. La del peregrino es una cosmovisión, por tanto, tridentina, ataviada de rasgos teológicos procedentes del universo barroco. Así pues, hubo unos primerizos visitantes de México al Medio Oriente, y, por la temprana fecha de su viaje, ellos no pudieron menos de ser peregrinos. Conforme avanza el siglo XIX mexicano, se radicaliza el ala liberal al grado de gestar un notable jacobinismo entre sus simpatizantes. Estos mexicanos adoptan una cosmovisión moderna, que negaba (no podía ser de otra manera) la herencia hispánica y su aneja mentalidad tridentina, en beneficio de los valores republicanos. Se

23 Ésta es la tesis medular del clásico de Edmundo O’Gorman, La superviviencia política novo-hispana. Algunos historiadores actuales han demostrado cómo la cosmovisión virreinal estaba tan arraigada en el México independiente, que la Independencia de la Corona no podía contraer la extirpación de esa cosmovisión. No hubo Modernidad, propiamente dicha, sino hasta el Triunfo de la República. El caso de los sufragios y el de las cortes, durante el siglo XVIII borbónico, si bien, no remiten al nacimiento per se de la ontología moderna - como se piensa corrientemente (como en José Antonio Aguilar y Rafael Rojas (coords.), El Republicanismo en Hispanoamérica. Ensayos de historia intelectual y política, México, Fondo de Cultura Económica/CIDE, 2014 (2002))— sí suponen el paso indispensable que le otorgó, a esa futura ontología moderna, un estatus de potencia. No es propiamente una Modernidad porque, como argumenta Rodríguez, ambos fenómenos proceden de la política de estirpe hispánica, que es a la postre tridentina. Cfr. Rodríguez, "The Birth of Representative Government”, en The Independence of Spanish America, pp. 75-106; Rodríguez, “Nosotros somos ahora los verdaderos españoles". La transición de Nueva España de reino de la Monarquía Española a la República Federal de México, 1808-1824. 
cosecha, así, una nueva mentalidad que abandonó cualquier concepto y cualquier categoría de talante teológico. Durante este siglo se transitó de la mentalidad teológica a la mentalidad profana. ${ }^{24}$ Tal proceso no hizo sino reflejarse, inclusive, en el acto histórico de viajar. Vemos así que se gesta, paralelo al tránsito de monarquía a república, un tránsito de la peregrinación tridentina al viaje moderno y mundano.

La peregrinación de los mexicanos tridentinos, como toda la tradición de peregrinaciones católicas, es un acto penitencial, de humillación, de expiación de pecados. ${ }^{25}$ Según la historia de las peregrinaciones, el peregrino esperaba un trayecto difícil, lleno de obstáculos, para alcanzar la Tierra Santa. Lograrlo le granjeaba indulgencias a sus pecados más graves. No hay suficientes viajeros mexicanos al Medio Oriente en la primera mitad del siglo XIX, debido a este mismísimo hecho: la peregrinación no es un viaje cómodo, es un acto de humillación. Aún más: un obstáculo inexorable para el peregrino, en su rumbo al "Oriente", es la continua presencia de no cristianos: herejes, cismáticos, apóstatas, relapsos, infieles, paganos, judíos. ${ }^{26} \mathrm{El}$

El mundo tridentino y el mundo moderno son dos categorías útiles para ilustrar la realidad histórica del siglo XIX mexicano. Edmundo O’Gorman habló de esta distinción, con sus propios términos, en relación con la realidad política. Usó los conceptos metafísicos de "ontología monárquica” y “ontología republicana”. La primera ontología es de estirpe hispánica, y por eso brota del catolicismo tridentino (esto es, el catolicismo contrarreformista formulado en el Concilio de Trento, corrientemente llamado "barroco"). La ontología republicana representa la adopción del proyecto de Modernidad occidental. La caracterización como tridentina procede de los numerosos análisis que se han hecho del mundo compuesto por un ethos barroco y su vínculo con la tradición ibérica (cfr. los más destacados: Echeverría, La Modernidad de lo barroco, y Maravall, La cultura del barroco. Análisis de una estructura histórica). Sin embargo, porque sé que no se restringe al mundo hispánico el concepto de barroco, ni tampoco al catolicismo brotado en Trento, he preferido aglutinar los rasgos barrocos y los católicos en el concepto de "tridentino". Por supuesto, estoy consciente de que un ethos tridentino no es, en lo absoluto, privativo del mundo hispánico. Pero los territorios tridentinos manifiestan muchas afinidades frente a otros ethoi. Difícil sería disputarlo, pues la Ética protestante de Max Weber consagra un nutrido espacio para comparar ambos imaginarios (cfr. Weber, La ética protestante y el espíritu del capitalismo, especialmente p. 223). Como reverberación de Weber, el membrete de "moderna" representa la contraparte de lo "tridentino". Aunque estoy al tanto de que Weber no hacía un vínculo inequívoco entre "lo moderno" y el capitalismo concebido en el espíritu protestante.

25 En las Penas Canónicas, existe el acto de la peregrinación penitencial. Igualmente existe la peregrinación de devoción. Una es una imposición canónica para expiar pecados, la otra tiene meros fines devotos. (Cfr. Vogel, “Le pèlerinage pénitentiel”, pp. 113-154).

26 Recuérdese las celebraciones litúrgicas tridentinas de Semana Santa. En las últimas Colectas Solemnes de la Misa de los Presantificados, durante el Viernes Santo, el celebrante pronunciaba tres intenciones finales: "Oremos también por los herejes y los cismáticos, para que nuestro Dios y Señor los libre de todos sus errores”; los fieles se arrodillaban y escuchaban: "Omnipotente y eterno Dios, [...] vuelve tus ojos a las almas seducidas por el engaño del diablo, para que estos corazones descarriados, dejando toda herética malicia, vuelvan al buen camino”. La siguiente intención decía: “Oremos también por los pérfidos judíos, para 
peregrino adolece de una pena inveterada: que la Tierra Santa permanezca domeñada por los enemigos de Cristo, los herejes de Mahoma: los mahometanos. Los peregrinos mexicanos, de acuerdo a su lógica tridentina, entenderán así a los musulmanes con quienes inevitablemente se cruzarán por su camino.

Los mexicanos modernos no entienden así las cosas. Para ellos, un viaje es un privilegio que sólo los acaudalados pueden costear. El viaje es, igualmente, fuente de conocimiento. Salta a la vista que, en la segunda mitad del siglo XIX, aumente el número de viajeros al Medio Oriente. La peregrinación beata ha dado lugar al viaje turístico, ${ }^{27}$ tan sólo posible en una sociedad moderna. Adecuada o inadecuadamente adaptada, la Modernidad inició su historia en México tras el Triunfo de la República. Y es tras este acontecimiento que surgen viajeros ansiosos por conocer el mundo entero. La figura del viajero mexicano consiste, ya no en sacerdotes ni religiosos, sino en abogados, políticos, militares, médicos, científicos, poetas. ${ }^{28}$

Justo es decir que los peregrinos no desaparecen con la llegada de la Modernidad. Señeros y aislados son los viajeros mexicanos plenamente ateos y jacobinos. La mayor parte de los viajeros mexicanos de la segunda mitad del siglo xix son católicos, y ejecutan, durante su mismo viaje, el turismo y la peregrinación de manera simultánea. Son quizás estos viajerosperegrinos los arquetipos de los viajeros mexicanos que, en el siglo XIX, visitaron el Medio Oriente. Ellos no van a interpretar a los musulmanes como meros herejes, también los interpretarán como los interpretan los modernos: o sea, como los “orientales", como hijos de la "civilización” islámi-

que quitando nuestro Dios y Señor el velo de sus corazones, vengan al conocimiento de nuestro Señor Jesucristo [...], oye los ruegos que te hacemos por la obstinada ceguedad de aquel pueblo". La última intención se escuchaba así: “Oremos también por los paganos, para que Dios Todopoderoso aparte de sus corazones la iniquidad, y abandonando sus ídolos, se conviertan al Dios vivo y verdadero". Las citas provienen de Villanueva, Oficio de la Semana Santa. Traducido al castellano é ilustrado con nuevas y copiosas notas, pp. 271-273. No usé la grafía del original. Ya los viajeros utilizan con mucha frecuencia el sustantivo tourista (no así el de turismo).

En el segundo volumen de Los extranjeros en México y los mexicanos en el extranjero, de Moisés González Navarro, hay un breve apartado donde se ve el perfil de los turistas. Considero que es muy útil para comprobar lo que he venido describiendo aquí. Intitulado "México descubre el mundo", el apartado ofrece sucintas descripciones de algunos viajeros mexicanos. Dos de ellos pertenecen a la primera mitad del siglo XIX, el padre Mier y Juan Nepomuceno Adorno. El primero arroja sentencias con puntas y ribetes tridentinos, el segundo viaja a Europa con motivos industrializadores. El resto de los viajeros que reseña son turistas, o sea, vástagos de la modernidad. El autor tan sólo localiza a tres viajeros de los que aquí hablaré (González Navarro, Los extranjeros en México y los mexicanos en el extranjero, pp. 412-440, esp. pp. 419-425). Los viajeros de que habla, salvo tres o cuatro, ya están presentes en Teixidor, Viajeros Mexicanos (siglos XIX y XX), pp. 11-144. 
ca, que cobran infinita curiosidad cultural para los viajeros. Y, sin embargo, aún se les considera como herejes. ${ }^{29}$ Ésta, la de los viajeros-peregrinos, es una mezcla de lógicas (la tridentina y la moderna) sumamente sugestiva que adelante se podrá apreciar con detenimiento.

Así pues, se estudiará los siguientes tipos de viajeros mexicanos:

- Peregrinos, cuya lógica tridentina interpretará a los musulmanes como herejes. Tienen ellos una lógica teológica.

- Viajeros (turistas), cuya lógica moderna interpretará a los musulmanes como orientales. Tienen ellos una lógica cultural.

- Viajeros-peregrinos, cuya lógica dual interpretará a los musulmanes como herejes y orientales simultáneamente. Tienen ellos dos lógicas paralelas: la teológica y la cultural.

Son realmente pocos los investigadores dedicados a escrutar la presencia histórica de mexicanos en el Medio Oriente. Desde luego, esta desatención está motivada por la dificultad de encontrar viajeros mexicanos decimonónicos en dicha región. Entre los investigadores, lamentablemente, hay una tendencia a concluir que los viajeros mexicanos eran sujetos marginales, deuteragonistas (por no decir tritagonistas), ${ }^{30} \mathrm{y}$, por ende, que sus viajes no

Recupero esta intuición de los pares de contraconceptos analizados por Reinhart Koselleck: "El mundo histórico [...] opera, en buena medida, mediante conceptos asimétricos que son desigualmente antitéticos” (Koselleck, op. cit., p. 157). Las antítesis que él estudia, grosso modo, son: (1) helénico contra bárbaro, (2) cristiano contra pagano y (3) humano contra inhumano. Los segundos contraconceptos priman en la lógica teológica, y, por ende, en el mundo tridentino. Los terceros contraconceptos priman en la ontología moderna. El "humano" es un concepto utópico, que funge como un sustantivo colectivo en el que, intrépidamente, hacen posada toda la variedad de individuos. Koselleck señala que tal universalidad no es probable. Por eso, el contraconcepto de humano es el inhumano y el infrahumano. Un musulmán es, para la ontología moderna, una clase de infrahumano, por su presunta falta de civilización. Más adelante lo comprobaré. Agradezco a Ilán Semo haber puesto mi atención sobre este escrito.

30 Ver el estudio — en seguida comentado—: Taboada, "Un orientalismo periférico; viajeros latinoamericanos, 1786-1920”. De menor importancia para esta investigación, ver también lo que dice Araceli Tinajero: "el discurso modernista [hispanoamericano del "Lejano Oriente"] nos ofrece el insólito viaje de una "periferia" a otra "periferia" (Tinajero, Orientalismo en el modernismo hispanoamericano, p. 33). Tampoco está muy lejos la hermenéutica que exhibe el tercer capítulo de Tyutina, "Hispanic Orientalism: The Literary Development of a Cultural Paradigm, from Medieval Spain to Modern Latin America”. Daniar Chávez también tropieza con esta misma piedra estudiando el viaje de Francisco Bulnes. Estima que su discurso es "irónico" (realmente quería decir contradictorio, o, a lo mucho, paradójico) dado su recurrente juicio de valor contra los "asiáticos", pues "quien lo emite es un hombre latinoamericano que [...] para la visión occidental es originario de un pueblo que queda fuera de la civilización y se inscribe en el ámbito de la barbarie" (Chávez, "Viajeros del siglo XIX: el linaje mexicano y las 11 mil leguas de Francisco Bulnes por el Hemisferio Norte”, p. 65). 
representaron más que un hecho aislado, relatado a partir de opiniones imitadoras, ${ }^{31}$ y aun de juicios insensatos. ${ }^{32}$

Los investigadores llegan al extremo de acusar que, en vista de que un viajero mexicano procedía de un país latinoamericano, y no de uno civilizadamente europeo, entonces su viaje no abriga mayor complejidad. Si los viajeros y los eruditos europeos, a la sazón, generaban una imagen muy tendenciosa de los "orientales", y sólo los infravaloraban, los viajeros mexicanos no pudieron menos de ser una versión empeorada de sus homólogos europeos (según concluyen los investigadores). Esta actitud europea, de infravaloración, fue conceptuada por Edward Said como Orientalismo. La actitud mexicana —emuladora barata de los europeos, según consienten los investigadores actuales - era un Orientalismo Periférico. ¿No es ésta una interpretación, en sí misma, tendenciosa y anacrónica? ${ }^{33}$

$\mathrm{Si}$, como hemos visto hasta aquí, los viajeros mexicanos que visitaron el Medio Oriente eran, o bien peregrinos, o bien turistas, o bien una mezcla de ambos tipos, ¿de dónde se puede concluir que eran periféricos para la "cultura occidental"? Todos estos viajeros se ufanaban de que México era partícipe de la tradición occidental. El peregrino se identificaba con el catolicismo tridentino, plenamente occidental. El viajero turista se identificaba con los valores de la Modernidad europea y de la República estadounidense, ambas plenamente occidentales. ${ }^{34}$ ¿El solo hecho de pertenecer a una región lati-

31 El orientalismo latinoamericano, “desde sus inicios, fue subsidiario del europeo”. Luego añade que la "dependencia de las fuentes europeas, la falta de originalidad, la posición marginal en el conjunto de la producción cultural, son características que nos remiten a un 'orientalismo periférico'” (Taboada, op. cit., pp. 286 y 287).

32 Su conclusión lee que los viajeros latinoamericanos mantenían "un modo de relatar viajes que lamentablemente reunió todos los defectos y pocas de las pocas virtudes que había tenido su modelo: el orientalismo europeo" (Taboada, op. cit., p. 305).

33 Considero superior la disquisición de Martín Bergel sobre su concepto de "Orientalismo invertido”. Este concepto, a diferencia del “Orientalismo periférico”, le da más importancia a la forma en que se forjó una visión del "Oriente”, en Argentina, a partir de un romanticismo endémico. Dice Bergel: "las efusiones orientalistas de Sarmiento y de otros románticos argentinos estuvieron por lo general subordinadas a ulteriores fines políticos o de conocimiento de lo social caros al paradigma civilizatorio que se pretendía impulsar" — esto es, no era una barata emulación, como en el "Orientalismo Periférico"- (Bergel, El Oriente desplazado, pp. 14-16). El concepto de Bergel pone hincapié, no ya en el siglo XIX, sino en las primeras décadas del siglo XX. Así es porque el efecto del Orientalismo invertido en dicha época, según Bergel, consistirá en una ulterior e insólita valoración positiva del "Oriente”. No me parece, sin embargo, que este fenómeno sea representativo de México, al menos no lo fue en esos tiempos de entreguerras, sino (si acaso) en la tumultuosa década de los sesenta. Pero este asunto no incumbe en el presente escrito.

34 "Ambas Américas son, pues, europeas; pero la diferencia que ocultó esa circunstancia y que intuyeron los conservadores y liberales mexicanos sin lograr penetrar en ella, es que, para usar una imagen, la América hispana fue un transplante de la cultura europea, tal como lo representaba España, mientras que la América anglosajona fue la planta, hasta entonces des- 
noamericana los relegaba a la periferia y a la barata imitación? He ahí un craso anacronismo, inspirado en el actual estatus tercermundista de América Latina. A propósito del Orientalismo de Said, este anacronismo en el que caen los investigadores es denominado Latinoamericanismo. ${ }^{35}$

Esta lógica anacrónica, que arroja a la periferia a los latinoamericanos, la reprobaron incluso los propios mexicanos decimonónicos. José María Tornel, dos veces gobernador del Distrito Federal en la primera mitad del siglo XIX, se cruzó con el relato que el conde austriaco, Isidore Löwenstern, compuso a propósito de su viaje a México en 1838. Tornel no puede dar crédito a la sarta de aseveraciones que el austriaco arremete contra los mexicanos. Deplora que Löwenstern contemple a los mexicanos "como una raza corrompida y degradada". ${ }^{36}$ Le parece naturalmente incomprensible que el viajero tache a los mexicanos de bárbaros. Tornel ve clarísimo lo contrario:

México no es uno de los pueblos del globo mas atrasados en civilizacion; y cuanto permiten sus antecedentes, las circunstancias actuales y los obstáculos que producen los trastornos civiles, innegable es que ha obtenido adelantos, que si no pudo percibir el viajero, es, ó porque sus ojos no son tan claros como los de un filósofo, ó porque le plugó cerrarlos ante los hechos que contradecian sus absurdas opiniones. ${ }^{37}$

Tornel sólo puede concluir que una descripción tan errada procede de una pluma malintencionada. "Mr. Lewenstern [sic] ha agotado el veneno de una pasion rencorosa, y ha trazado sus líneas para no ser creido de persona

conocida, que de la semilla europea le brotó al suelo del Nuevo Mundo. Y fue en esa diferencia en lo que se fundó el "europeísmo" que la tendencia tradicionalista quería "conservar", y el "americanismo" que la tendencia moderna quería "imitar”" (O’Gorman, La supervivencia política Novo-hispana. Monarquía o República. Reflexiones sobre el monarquismo mexicano, pp. 92-93).

35 No es casual el hecho de que los latinoamericanos reproduzcan su propia infravaloración. Said alertó de cómo los árabes estaban produciendo estudios que caían en el Orientalismo: "En efecto, hay algunos motivos para alarmarse por el hecho de que su influencia [la del Orientalismo] se haya extendido al "Oriente" mismo: las páginas de libros y revistas en árabe [...] están repletas de análisis de segundo orden por los árabes sobre la "mente árabe”, el "Islam" y otros mitos. [...] El hecho es que el Orientalismo se ha adaptado con mucho éxito al nuevo imperialismo, en el que sus paradigmas dominantes no contienden, o siquiera confirman, el persistente designio imperial de dominar Asia” (Said, Orientalism, p. 322). La escuela decolonialista de Said derivó en el "latinoamericanismo" ( $c f r$. Mendieta, "Ni orientalismo ni occidentalismo: Edward W. Said y el Latinoamericanismo").

36 Tornel, "Bibliografía: México, ó las Memorias de un viajero: por Isidoro Lowenstern, autor de: “Los Estados Unidos y la Habana”, p. 244.

37 Ibíd., p. 247. 
alguna, porque la perversidad que atribuye á un pueblo civilizado, es una paradoja que jamas autoriza la buena crítica”. ${ }^{38}$

\section{LOS VIAJEROS Y SUS MUSULMANES}

Fue el padre José María Guzmán al que se ha reputado como el primer mexicano en el "Oriente". ${ }^{39}$ Su misión, en 1834, era abogar, en Roma, por que fray Antonio Margil ${ }^{40}$ fuera beatificado. Dada la demora del proceso, tomó ventaja de su localización para realizar la peregrinación que a todo buen creyente impacienta, la de Tierra Santa. Este personaje condensa todos los rasgos de la ontología tridentina. El discurso que procede de su pluma alude a un mundo ordenado como cristiandad. Luego, el musulmán es un Otro que desequilibra la cristiandad.

Lo cristiano se vuelve el parámetro lo mismo para lo inteligible que para lo ininteligible. Y esto explicaría, quizá parcialmente, por qué Guzmán no puede distinguir entre el gentilicio turco y el creyente musulmán. A veces usa el gentilicio atinadamente, en referencia a las facultades civiles, y a veces, también, describe correctamente al religioso en su práctica, pero él no parece estar bien consciente de la distinción. No lo está, ya sabemos, precisamente por su cosmovisión tridentina, y no por una inteligencia embrutecida, pues turco y "mahometano" no son sino metonimias de hereje. ${ }^{41}$

Ibíd., p. 248.

39 Se cuenta recurrentemente que el primer mexicano que viajó al Medio Oriente fue José Mariano Michelena. La anécdota reza que en 1828, llevó granos de café de Moka (Yemen) a México, y así se generalizó el uso del grano. Algunos investigadores de la historia del café mexicano echan mano de este relato, sin cuidar el debido fundamento. Por fortuna, Armando Bartra, Rosario Cobo y Lorena Paz sospechan de su verosimilitud, y por eso recuentan que la "anécdota la cuenta en 1896 Eduardo Ruíz, en su Historia de la Guerra de intervención en Michoacán, la transcribe Alfonso Reyes, en Minuta, de donde la recoge Salvador Novo para su Cocina Mexicana. Directamente de don Alfonso la retoma Paco Ignacio Taibo I, en Memoria de Reyes, de donde la cita Elisa Ramírez en su trabajo documental sobre el café" (Bartra, Cobo, Paz, La hora del café. Dos siglos a muchas voces, pp. 68-69). De hecho, encontré que la referencia más antigua de esta anécdota no es de Eduardo Ruíz, sino de Matías Romero: "es de suponerse que la semilla del café de Moca que el general Michelena trajo á Michoacán, á su regreso de la misión que llevó á Londres, en 1828, se propagara hasta Colima” (Romero, “Tercera parte. Apéndice. Artículos sobre el cultivo del café en varios Distritos de México y en Alta California”, p. 150).

40 Fray Antonio Margil de Jesús (1654-1726), misionero franciscano de Valencia, fue una figura preponderante para la propagación de la fe y, más especialmente, de la espiritualidad guadalupana. Las misiones de San Antonio (Texas) lo elevan a rango de protagonista (Cfr. Salinas, Historia de la cultura nuevoleonesa, pp. 72-74).

41 Basta esta referencia del teólogo tridentino Juan de Lugo y Quiroga, S.J.: "Turcae et mahometani possunt vera fide supernaturali credere unum Deum remuneratorem supernaturalem" (Lugo, "Disputation XII, Sectio III.", De virture Fidei divince, p. 179). A propósito dice 
Assia Mohssine, única estudiosa escrupulosa del peregrino, realiza, en principio, una observación muy feliz del relato viajero. ${ }^{42}$ Analiza el relato en tónica semiótica. Dice que "es construido, a grandes líneas, sobre las convenciones del género viático, a partir de la experiencia del viajeroperegrino". ${ }^{43}$ Se puede decir que Mohssine, con suma perspicacia, notó que el relato es una "forma discursiva", concepto que útilmente propone Perla Chinchilla. ${ }^{44}$

Y, en efecto, el relato de esta peregrinación echa mano de recursos discursivos propios de otros relatos de peregrinos. Pero Guzmán está pensando en las formas discursivas que son propias de su linaje tridentino, y no, como Mohssine parecería insinuar, en los relatos de viajeros franceses. Hay mucho mayor parentesco entre el impreso de Guzmán y, por ejemplo, la Historia de cosas del Oriente, de Amaro Centeno publicado en 1595, que con los relatos, tan mentados aquí, de Lamartine y Chateaubriand. ${ }^{45}$

La cristiandad en la que vive Guzmán se refleja en el desprecio por los musulmanes. El cual se gesta por la falsedad de su religión — pues sólo Cristo es la verdad-, según entiende el teólogo. No hay juicios tolerantes para las prácticas del musulmán. El salat de la mezquita es acicate de burla, el Adhán del muaddín se reduce, según escucha, a gritos destemplados, ${ }^{46} \mathrm{y}$ cuando nota la presencia de los faquires sufíes, Guzmán lleva el vituperio hasta el extremo diciendo que a "estos hombres sucios y desvergonzados reputan por santos los turcos, y se tienen por dichosos, tanto hombres como

Said: "Una restricción que influía entre los pensadores cristianos que intentaban entender el Islam era una analogación: ya que Cristo es la base de la fe cristiana, se asumía - muy incorrectamente - que así Mohammed era para el Islam lo que Cristo al cristianismo. De ahí el polémico nombre de "mahometanismo" dado al Islam" (Said, op. cit., p. 60). Cfr. Mohssine, "El relato de viaje de José María Guzmán por Oriente (1837). Entre construcción identitaria y palabra panfletaria”, pp. 65-79.

43 Ibíd., p. 69.

44 Esto es, "el artefacto compuesto por una semántica condensada en un discurso verbal y por una materialidad, cuyo conjunto denota una regularidad que permite una distinción específica en el contexto de múltiples campos culturales" (Chinchilla, "Las 'formas discursivas'. Una propuesta metodológica”, p. 16).

45 Cfr. Centeno, Historia de cosas del Oriente. Contiene una descripcion general de los Reynos de Assia con las cosas mas notables dellos. La Historia de los Tartaros y su Origen y principio. Las cosas del Reyno de Egipto. La Historia y sucesos del Reyno de Hierusalem, Primera y Segunda parte.

46 "En los templos magnificos que tenian en aquellos lugares los católicos, han hecho los turcos sus mezquitas ó mosqueas [...], y allí ocurren continuamente á hacer su oracion; pero con tales acciones, gestos y ceremonias, que algunas veces me movian á risa, y otras me causaban compasion" (Guzmán, Breve y sencilla narracion del viage que hizo a visitar los santos lugares de Jerusalén el P. Fr. Jose Maria Guzman, Americano, hijo del Colegio Apostólico de nuestra Señora de Guadalupe de Zacatecas en la República Mexicana: quien la dedica á su patria. Publícala un amigo del autor, p. 35). 
mugeres, con tocarlos ó besarlos, lo que prueba su espantosa ceguedad, ignorancia y fanatismo", y su ultraje culmina cuando dice que ellos tienen "otras estupideces que asombran, y que seria muy molesto referir". ${ }^{47}$

\section{Cuadro 1}

Analogías discursivas

\begin{tabular}{ll}
\hline \multicolumn{1}{c}{$\begin{array}{c}\text { Breve y sencilla narración del } \\
\text { P. Guzmán }\end{array}$} & \multicolumn{1}{c}{$\begin{array}{c}\text { Historia de cosas del Oriente } \\
\text { de Amaro Centeno }\end{array}$} \\
\hline $\begin{array}{l}\text { El terreno de Levante me parece mui } \\
\text { fértil, pues noté que todas las frutas de } \\
\text { la Europa se dan allí con abundancia i } \\
\text { de mui buena calidad, especialmente el } \\
\text { albaricoque que nosotros llamamos } \\
\text { chabacano ó damasco, es allí mui rico } \\
\text { (p. 44). }\end{array}$ & $\begin{array}{l}\text { El Reyno de Turquia es muy grande, y } \\
\text { Ricone muchos mineros de Plata, } \\
\text { muchantidad y abunda de todas las } \\
\text { Viandas, de frutas y de Vino, ay } \\
\text { muchos Animales mayormente muy } \\
\text { buenos cauallos (f. 11) }\end{array}$ \\
$\begin{array}{l}\text { Pero hablemos ya algo sobre las gentes } \\
\text { que habitan los paises del Levante. }\end{array}$ & $\begin{array}{l}\text { En este Reyno de Turquia, abitan } \\
\text { quatro naciones de gentes, que son }\end{array}$ \\
$\begin{array}{l}\text { Estas se pueden dividir en turcos que } \\
\text { son los dueños actuales del terreno; en } \\
\text { latinos que son los relijiosos } \\
\text { franciscanos, i otros algunos católicos } \\
\text { que estan bajo su rito: en griegos, en } \\
\text { armenios, gofitos ó coptos, maronitas; i i } \\
\text { finalmente los desgraciados judios. } \\
\text { (p. 46). }\end{array}$ & $\begin{array}{l}\text { tres son de Christianos, que biuen de } \\
\text { sus tratos mercantiles y đlabrar la }\end{array}$ \\
\hline
\end{tabular}

Todo es cristocéntrico para el peregrino. Tanto es así que, cuando visita el Cenáculo —el lugar donde, según la Tradición, aconteció la Última Cena- exclama: "Este lugar tan venerable y tan sagrado, está por nuestros pecados hecho mesquita de turcos, y no dejan entrar allí a los cristianos; pero á mí por providencia de Dios me permitieron entrar á hacer oracion”. ${ }^{48}$ Se mantiene, pues, un ordo mundi en el que el pecado de la "humanidad" desencadena una serie de derrotas para la cristiandad, pero que pueden ser mitigadas por mediación de las obras y la fe.

47 Ibíd., p. 41.

48 Ibíd., p. 19. El resaltado es mío. 
Mohssine permitió que su estudio languideciera al admitir la falsa periferia. Interpreta que el padre Guzmán no resistió al influjo europeo porque presenta un apéndice "más científico" en su libro. Por motivos semánticos que prefiere omitir, Mohssine establece una sinonimia entre lo europeo y lo científico (convendría que revisara, cuando menos, apellidos como Alzate, Elhuyar y Del Río). Así y todo, yo no me atrevería a membretar de científico al apéndice que añade Guzmán, sino que lo inscribiría en esa tradición de impresos que escruta la "Tierra Santa" y el "Oriente", tal y como es notable en las analogías entre Guzmán y Centeno.

Si Guzmán añade señeros pasajes en donde no se desdeña algún elemento "turco", se debe a que ese elemento compagina bien con el orden cristiano. Esto despunta - como agudamente observa Mohssine ${ }^{49}$ - cuando habla de "Mehmet-Ali" (el revolucionario de Egipto) casi como un héroe. ¿Por qué? Sencillamente, porque se desentendió de la política "del Gran Turco de Constantinopla [pues] con la proteccion que ofrece á los europeos [...] ya no son tantas las vejaciones que experimentan los religiosos". ${ }^{50}$

Así, también, Guzmán templa su uso de adjetivos ofensivos cuando describe la devoción que muestran las "turcas" en el lugar milagroso donde, según se dice, la Virgen María derramó algunas gotas de su leche materna en el suelo. El acto piadoso que ahí opera consiste en que quien adolece de agalactia visita el sitio para generar leche. La devoción que observa en "las turcas" y "los turcos" es insólita. "Es esto en tal grado, que [...] casi de su cuenta corre que no falte el aceite para las lámparas de aquella devota hermita. La miran con tal respeto y veneracion, que allí van los dichos turcos á hacer los juramentos que jamás han de violar”. ${ }^{51}$ Casi parecería, Guzmán, ignorar que los musulmanes también veneran a Maryam. De hecho, su observación insinuaría que este milagro es reserva exclusiva de la "verdadera religión”, el catolicismo romano. Por eso, la referencia al turco funciona como una amplificatio retórica, un instrumento para persuadir, de una buena vez, sobre el portento extraordinario que ahí se manifiesta. Uno que hasta a los "herejes" hace prosternarse.

No muy distante se columbra el siguiente escrito viajero que tocaré. Casi veinte años después de Guzmán, en 1862, publica su extenso relato de peregrinación el padre Rafael Sabás Camacho y García, futuro obispo de Querétaro. ${ }^{52}$ Su peregrinación no es menos piadosa que la del padre Guzmán, pues está investida con la presencia de hombres y mujeres consagrados a la vida

Mohssine, op. cit., p. 75.

Guzmán, op. cit., p. 39. Nótese el nombre tan cristiano que le impone a Estambul.

Ibíd., p. 26.

Cfr. Camacho, Itinerario de Roma á Jerusalén escrito el año de 1862. 
religiosa. Su peregrinación está, además, coronada por la compañía del célebre futuro arzobispo de México, Pelagio Antonio de Labastida (y sus dos sobrinos). ${ }^{53}$

Como es de esperarse, el padre Camacho también está impregnado de la ontología tridentina. Sin embargo, hay en sus palabras un acento de añoranza, o, aún más, de nostalgia. El padre Guzmán también lo presenta, pero ambos acentos pusilánimes no son equivalentes. El dolor de éste es un dolor muy tradicional; ése que, como jaculatoria, itera y reitera la miserable condición del cristianismo en Tierra Santa. Es un discurso que está sedimentado en la identidad latina, que es una identidad acongojada por la irremediable rendición de la Jerusalén cristiana al hereje. ${ }^{54}$ La fatalidad que se asoma en el escrito del padre Camacho, sin embargo, no es tan atávica. Es la que nace, más bien, a raíz del paulatino desmoronamiento de la Iglesia que los mexicanos, a la sazón, atestiguan.

Esta peregrinación acontece un lustro después de promulgarse la Constitución de 1857. Es el principio de la derrota para la ontología tridentina. Un evento simbólico que delata este desmoronamiento es, sin duda, el envío de las tropas del gobernador Juan José Baz a rodear la catedral por la negativa que propinó el arzobispo José Lázaro de la Garza a que las autoridades civiles participaran en los oficios de la Semana Santa. ${ }^{55}$ La ontología moderna comienza a corroer la ontología tridentina. Y, por eso, surgen ásperos defensores de la Iglesia. "Sólo los últimos años de los cincuenta y primeros de los sesenta verán la consolidación de una escuela católica de pensamiento abiertamente hostil al liberalismo" 56 —antes no.

En suma, cunde la congoja en esta peregrinación. La presencia del obispo Pelagio Antonio de Labastida es aún más elocuente sobre esta derrota. En 1856, el prelado fue expulsado de México por rechazar la propuesta que ofreció Ignacio Comonfort a la Iglesia de financiar con 10,000 pesos mensuales al gobierno. ${ }^{57} \mathrm{El}$ obispo osciló entre el retorno y el destierro, entre

53 Uno de estos dos, que estudiaron en Oscott (Birmingham), fue José Antonio Plancarte y Labastida (cfr. Woestmann, O.M.I., “Mexico - Opportunity Turned Down”; también la completa biografía —aunque hagiográfica a ultranza - de Plancarte fue útil: García, C.M.F., El Padre Plancarte: figura prócer de la Iglesia católica mexicana).

54 En el segundo capítulo de Yeager, Jerusalem in Medieval Narrative, hay un interesante recuento de cómo la "pérdida” de Jerusalén forja un discurso de identidad que, a menudo, se instrumentalizó para legitimar a un grupo en menoscabo de otros. En este caso, Yeager habla de la superioridad que los ingleses atribuyeron a Ricardo Corazón de León frente al rey Felipe de Francia.

55 Cfr. García Ugarte, Poder político y religioso. México, siglo XIX, p. 680.

56 Connaughton, Entre la voz de Dios y el llamado de la patria. Religión, identidad y ciudadanía en México, p. 242.

57 Cfr. García Ugarte, op. cit., p. 539. 
Cuba, Nueva York y Roma, siempre con miras frustradas a regresar al terruño. ¿No es este hombre la encarnación de la derrota tridentina?

Entendido parejo escenario, cobra sentido la flagrante violencia que este relato lleva al colmo. El Itinerario de Camacho es, ante todo, un escrito defensivo contra las amenazas inveteradas de la cristiandad. Su repetida furia se desata siempre que visita lugares sagrados:

Pero, ¿qué es esto? me preguntará el lector. ¿Qué tienen que hacer los turcos en el Santo Sepulcro? ¡Ah! esta es una desgracia digna de lamentarse. Hoy los turcos después de haberse apoderado de la ciudad, son los verdaderos dueños del Santo Sepulcro: ellos tienen las llaves de la iglesia, y cuando se necesita entrar, hay que suplicarles y pagarles para que la abran [...]. Esto de que los turcos den licencia para entrar, es una de tantas humillaciones por que tiene que pasar el peregrino que visita los santos lugares. ${ }^{58}$

El mismo sitio que enfureció al padre Guzmán, el Santo Cenáculo, parece exacerbar al padre Camacho: "Antiguamente esta iglesia pertenecia á los padres de Tierra Santa; hoy los turcos se han apoderado de ella y la han convertido en mezquita, ó mas bien dicho en basurero; tal es el estado de suciedad en que se encuentra”. ${ }^{59}$ Lo mismo que Guzmán, para Camacho los musulmanes también son individuos despreciables, dado que son seguidores de un heresiarca: "Da mucha lástima que tanto fervor y exactitud de los pobres mahometanos, para cumplir con sus deberes religiosos, no sea empleado en una causa mas digna, profesando la verdadera religion”. Hierve en el padre Camacho una ira intransigente porque la sociedad compuesta por estos herejes tiene bien afianzada su religión, en tanto que allá, en su nación mexicana, la religión es ruina. "iQué vergüenza para los que profesamos la verdadera y santa religion de nuestro Señor Jesucristo, que los mahometanos, sectarios de errores tan groseros, nos den que imitar en materia de exactitud y fidelidad en el cumplimiento de nuestros deberes!". ${ }^{60}$

A mi parecer, el Itinerario del padre Guzmán es una nutrida fuente para escrutar la mirada tridentina sobre los musulmanes. La razón que se aduce para constatar esto descansa en la remarcada desesperación de sus afirmaciones, puesto que la Iglesia ni siquiera existirá para la ley (a partir de 1874).

Hay que esperar casi una década para tener un nuevo relato viajero. Se trata de Egipto y Palestina, de José López-Portillo y Rojas, famoso autor por pertenecer al canon de literatura mexicana. En su tiempo fue un prominente

Ambas citas proceden de ibíd., p. 164. 
abogado tapatío de factura liberal moderada y de notable condición intelectual. Al terminar sus estudios, en 1871, su adinerada familia lo manda a recorrer el mundo. El viaje surtió buenos efectos, pues así nace su primer libro en dos volúmenes. "Los países que visitó fueron de lo más diverso: primero Estados Unidos, Irlanda, Escocia e Inglaterra; luego, Francia - donde conoció a varios escritores con los que mantuvo correspondenciae Italia y, finalmente, Egipto y Palestina”. ${ }^{61}$

A diferencia de los dos peregrinos, el viaje de López-Portillo es más mundanal. Acaso dos indicios para subrayar esta condición reposen sobre su estatus seglar y en el puesto postrero que tiene su visita "al Oriente" dentro de su Tour du Monde. No obstante la diferencia entre los viajeros, se preserva una continuidad indisputable. El "Oriente" no se entiende si no consiste en beatitudes y santiguadas. Oriente, tanto para los hijos de la ontología tridentina como para López-Portillo, es, inexorablemente, una hagiotopía. López-Portillo insinúa la mutación, digamos, la contrastante consistencia entre su viaje a Europa y su viaje a Oriente: "Aquí me embarcaré para caminar á Oriente, y prepararé mi escalvina y mi báculo de peregrino", ${ }^{62}$ Tras bambalinas, se retira el vestuario de viajero y, en nuevo escenario, asume el rol de peregrino. Lo que quiere decir que ambos, viaje y peregrinación, no son actos intercambiables.

El viaje-peregrinaje de López-Portillo acontece en una circunstancia que presenció la anonadación de la opción monárquica y el menoscabo del poder temporal de la Iglesia. Florece una nueva ontología en el México que moldeó el pensamiento del abogado viajero. López-Portillo es un dechado de la mezcla de ontologías, es un pensador que tiene su fe en el aposento privado más que en la talla de las posibilidades y su devenir. Está en un momento histórico donde ambas ontologías tienen igualdad de intensidad. Veremos, pues, cómo López-Portillo tiene presentes los dos discursos de ambas ontologías.

Los musulmanes, para López-Portillo, todavía son contrincantes: “Ahora la tierra de los hebreos, que es segunda cuna del género humano, se encuentra habitada por infieles que no la veneran, sino que la oprimen y la ultrajan". ${ }^{63}$ En resumen, los "mahometanos son supersticiosos". ${ }^{64}$

Cuando relata su visita al "Árbol de la Virgen", que — dice la Tradición - resguardó en su sombra a la Sagrada Familia, procede a confesarse: "La verdad es que no pueden darse razones ni pruebas decisivas en pro ni en 
contra de su autenticidad; pero para mí, así como para otras almas que aborrecen el descreimiento, este sicomoro es realmente el 'árbol de la Vírgen "”. ${ }^{65}$ Pero López-Portillo parecería no aborrecer tanto el descreimiento en su visita a la Mezquita de Barquq. Su guía, Fortunato, y su compañero italiano de excursión, apellidado Felleti, aprenden que en esta mezquita hay un cinturón y una túnica que usó el sultán mameluco Al-Zahir Barquq. Según les comentó un musulmán, tanto el cinturón como la túnica son objetos milagrosos que curan los males de los creyentes.

— En ese caso, dijo Felleti, seria inútil que yo me echase encima la túnica y me ciñese el cinturon para quitarme la vejez, que es una atroz enfermedad [...] porque no tengo fé.

Fortunato rió, yo reí y el mahometano nos envolvió á todos tres en una mirada furibunda. Para quitarle el enojo le dí algunas piastras de plata al salir de la mezquita, y con esto quedó satisfecho. ${ }^{66}$

Pareja sentencia pronuncia - y esto es de advertirse - cuando visita la actual Capilla de la Ascensión, en Jerusalén, donde Jesús se elevó a los cielos de acuerdo al relato evangélico de san Lucas (24, 50-52). Ahí hay una piedra donde, según creen los peregrinos, quedó imprimida la huella de Jesús antes de ascender. Cuando López-Portillo viajó, la Capilla era una mezquita. Por eso dice: "Los musulmanes veneran esta huella diciendo que Jesucristo la dejó al subir a los cielos. Muchos cristianos dan asenso á tal aserto; yo respeto su modo de pensar, pero para mí esta huella es apócrifa”, ${ }^{67}$ ¿Por qué, pues, en sitios cristianos los milagros son verosímiles, mientras que en sitios musulmanes no? Claro está: para un cristiano, un sitio de devoción para herejes no puede ser verdadero.

Pero, a pesar de que los musulmanes son, para él, dignos de desprecio, López-Portillo encuentra méritos en ese país de musulmanes que recorre: "no seria malo que algunos pueblos liberales y cristianos tomasen lecciones de liberalismo de este desventurado país oriental, que gime bajo las garras de los déspotas coronados". ${ }^{68}$ El discurso de López-Portillo empieza a manifestar que puede dar tregua a sus enemigos.

Vimos cómo los peregrinos anteriores, Camacho y Guzmán, estiman positivamente a los musulmanes sólo si el cristianismo sale bien parado. López-Portillo no es salvedad. Pero su pensamiento se distingue por apreciar

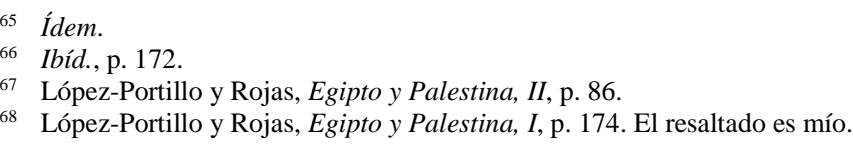


sin injurias a los musulmanes cuando apela a la historia, o al arte, o a la filosofía. La "cultura” islámica, vista desde el ángulo profano, trastorna el desprecio por los "herejes". Fortunato, su guía, lo lleva al palacio donde habita el "Sheikh Saddat". Este personaje, que al parecer fue un sayyid respetado en El Cairo, ${ }^{69}$ recibió con suma hospitalidad a López-Portillo. Intercambiaron impresiones, hablaron de política, y López-Portillo quedó complacido porque el sayyid tenía noticia de quién fue Benito Juárez. El jardín de su anfitrión le llevó a sentimientos históricos sublimes: "Este jardin me recordó los bellos tiempos del Islamismo, cuando los sectarios de Mahoma eran sabios y artistas". ${ }^{70}$ En suma, una cosa es que los musulmanes sean herejes, y otra, muy diferente, es que pertenezcan a la "civilización" islámica. Pero todavía no se puede ofrecer el epíteto de pacifista a LópezPortillo, pues sigue deplorando rasgos del musulmán coetáneo:

El 'sheikh', como buen mahometano, es sumamente corrompido en sus costumbres. Gusta no solo de las mujeres, sino tambien de los niños de once á trece años, de los que tiene siempre cuatro ó cinco en su compañia. Esto es muy horrible, pero en Egipto no hay quien fije la atencion en ello, porque tal costumbre es generalmente admitida. ${ }^{71}$

Es extraordinariamente sugestiva su mezcla de ontologías, pues lo que López-Portillo considera como el beneficio de la Modernidad, la "civilización”, tiene, para él, como efecto indisociable la “evangelización”. Declara que, con esta Modernidad venida a Egipto, "no solamente progresa materialmente el país, sino que se prepara á recibir nuevamente la luz del Evangelio, que en los primeros siglos del cristianismo brilló con sus mas puros resplandores". ${ }^{72}$ Este destino al que, felizmente, se ha embarcado Egipto es el imperativo de toda existencia, pues "Dios no quiere mas que el triunfo de su religion, la civilizacion del mundo y la conversion hácia él de la humanidad entera". ${ }^{73}$

La irrupción europea al Imperio otomano es razón de esperanza. En esa década de 1870, las penetraciones de franceses y de británicos adquirían ya dimensiones proverbiales. ${ }^{74}$ La esperanza de López-Portillo de que el cris-

La casa es un monumento histórico en el barrio Sayeda Zainab de El Cairo, conocido como Bayt Al-Sadat Al-Wafaiya (بيت السادات الوفائية).

70 Ibíd., p. 181.

71 Ibíd., p. 182-183.

72 Ibíd., p. 196.

73 Ibíd., p. 257.

74 La firma del Tratado de París, en 1856, incluía al Imperio Otomano en comunidad virtual con los países europeos. La fundación del Banque Impériale Ottomane en 1862 hizo de ella 
tianismo triunfe, desatada por la presencia europea, es inexpugnablemente enérgica. Inclusive, se puede percibir en sus palabras un siniestro discurso de Cruzada: "la patria de Jesus, justo es que pertenezca á sus hijos; es la tierra que el Redentor empapó de su sangre, es la patria de los redimidos en el Calvario!". ${ }^{75}$ El temor de que la religión deviniera ruina —como sucedía en México- es anestesiado ante este nuevo panorama de un inminente triunfo cristiano.

El hecho es que los musulmanes de López-Portillo son algo más que meros herejes. Se recordará cómo Camacho y Guzmán se mortificaban por la presencia de guardias otomanos en los lugares sagrados. Ambos peregrinos achacaban, a la conducta de estos guardias, una naturaleza deliberadamente hostil en contra de los cristianos. Pero López-Portillo tiene otra opinión:

Es sumamente desagradable la impresion que causa la presencia de aquellos turcos. La servidumbre que pesa sobre este lugar se ve luego de bulto y ofende la dignidad del cristiano, del creyente, del adorador de estos sitios sagrados. Se piensa además, que los turcos son irreverentes por mofa y desprecio, y que adrede se reclinan de descuidada manera, y fuman sus pipas, con el objeto de causar agravio á los que profesan la religion cuyos principales hechos en aquel recinto se cumplieron. Pero en realidad no es así, pues los mahometanos se conducen de la misma manera en sus mezquitas. Dentro de ellas, sobre las esteras se recuestan, y derwishes, imanes y pueblo, todo el mundo fuma. ${ }^{76}$

López-Portillo prefiere dar otras explicaciones a la conducta del musulmán. Ofrece un género de explicación que, en una palabra, no es teocéntrica sino, más bien, profana y empíricamente observable. Sus ejercicios de explicación son incontables, cuyos silogismos presentan soluciones históricas, conductuales y culturales. Una explicación que aparece repetidas veces es la que ofrece al porqué del velo integral.

Los celos exagerados son siempre inícuos, y forman indispensablemente una víctima, que es la parte débil, que se sacrifica sin recompensa. Así, los mahometanos que ponen tanto esmero en vigilar á la mujer, en ocultarla y esclavi-

la organización financiera más importante del imperio. La Ley de Nacionalidades decretada en 1869 reconocía personalidad jurídica a "no musulmanes" (en sustitución del concepto islámico de dhimmi). El mismo año se inaugura el Canal de Suez a manos de Ferdinand conde de Lesseps. Estos aumentos de presencia europea alcanzan su cúspide con el inicio de la vida parlamentaria otomana, en 1876, y con el estilo de vida Alla Franca del sultán Abdülhamid II (cfr. Hanığlu, A Brief History of Late Ottoman Empire, p. 74, p. 92, pp. 100-102).

75 López-Portillo y Rojas, Egipto y Palestina, II, p. 100.

76 Ibíd., p. 49. El resaltado proviene del original. 
zarla, pasan volubles de un amor á otro, entre las beldades de sus bien poblados serrallos. Por esto creo que con razon se ha dicho que los celos son hijos mas bien que del amor, del amor propio. ${ }^{77}$

También adjudica a otras causas el —para él— extraño precepto de no beber alcohol de los musulmanes.

los musulmanes creen cumplir en tanto que no beben vino, pues con buena ó mala fé toman el precepto á la letra. El 'hatshish,' pues, y otra infinidad de pastas ó pastillas que hacen al hombre 'alegre,' como dicen los árabes, vienen á suplir la falta de bebidas espirituosas, así como el tabaco. Por esto los mahometanos aman tanto los aromas que desvanecen y son tan grandes fumadores. $^{78}$

Esta concatenación de explicaciones sólo puede ser posible en una ontología moderna, en que los individuos dejan de ataviarse con rasgos teológicos, y adquieren una consistencia más material. Se puede decir, quizá trémulamente, que inician las descripciones antropológicas. No se olvide que el "concepto universal” de esta ontología es precisamente el objeto antropológico por antonomasia: el Humano y ya no el Cristiano.

En 1874 y en 1875 acontecen dos de los viajes más temerarios, y, por eso, más significativos. Se trata, primero, del viaje que registra el controvertido Francisco Alonso de Bulnes. Acompaña a la comisión científica encabezada por Francisco Díaz Covarrubias, a propósito de la observación astronómica del paso de Venus por el disco solar, visible en Japón (y otras partes de esas latitudes). El otro es el primer viaje que realiza el insaciable médico militar Ignacio Martínez Elizondo. ${ }^{79}$ Estos viajes, innegablemente emblemáticos, coinciden en una circunstancia: tanto Bulnes como Martínez son ríspidos apologetas del Liberalismo. Estamos ante los primeros viajeros que visitaron el Medio Oriente sin mediación del acicate religioso.

Ambos enarbolan los blasones de la ontología moderna. Francisco Bulnes dice: "Exceptuando la moral científica, todas las demás quedan bajo el dominio del termómetro, y debatiéndose entre el temperamento linfático y el

77 López-Portillo y Rojas, Egipto y Palestina, I, p. 189. También: "Pues es de saberse que los celos orientales no permiten á las mujeres mostrarse en público, ni para orar en las mezquitas; los hombres van al templo, y las mujeres se encomiendan á Alá sin salir de su cautiverio, que es la habitacion de sus padres ó maridos” (pp. 151-152).

78 Ibíd., p. 83.

79 Para fines prácticos, citaré las impresiones que Martínez plasma sobre los musulmanes en sus dos relatos viajeros: Recuerdos de viaje (de su viaje de 1875) y Viaje universal (de su viaje alrededor del mundo de 1883). 
sanguíneo" ${ }^{80}$ Ignacio Martínez se propuso, durante su travesía, formular juicios "tan imparciales y justos como pueden ser los de un hombre honrado. Al calificar los hombres y las cosas" que observa, intentaría no recordar que es "mexicano, ni liberal, ni descendiente de señalada raza, sino sólo hombre que toma nota de lo que vé, en beneficio de la humanidad". ${ }^{81}$

Pero su persuadido temperamento republicano no prorrumpe, del todo, en vituperios contra la cuestión religiosa. Es más, sus palabras tienen una inclinación por apreciar con circunspección las manifestaciones religiosas del mundo. Bulnes lo declara sin melindres:

En cuanto a las religiones, cada uno podrá reconocer á su Dios ó á su profeta en la fuerza de los atributos divinos y con el prestigio de un ilimitado poder sobrenatural.

En vez de colocarme en el terreno ardiente de una discusión que compromete el eterno reposo de un ser ó su felicidad infinita, haré pasar las mas vistosas decoraciones del Olimpo moderno. Dar á conocer los cultos, exponer las causas que han trasplantado en las conciencias un millar de dioses altivos, terribles ó bondadosos y dejar ver con una prudencia casi helada los modos absorventes del fanatismo, ese lodo de las creencias, serán los únicos elementos de que me serviré para expresar algunas de las relaciones metafísicas que el género humano pretende sostener con la eternidad. ${ }^{82}$

Quizá es esta indiferencia lo que explique por qué los musulmanes le valen tan notable ausencia. Aventura muchas opiniones de encomio sobre la colonia armenia en el puerto de Adén, y otras tantas, pero de oprobio, sobre los judíos que ahí habitaban. Los musulmanes no fomentan más que dos comentarios frugales. En su paso por Hong Kong, Bulnes realiza digresiones sobre la panoplia de culturas ahí presentes. Entre sus palabras, se presenta una interesante comparación: "Como he dicho anteriormente, los adeptos de Confucio son libres pensadores; de la religion de Boudha se ocupan solo los sacerdotes y únicamente los musulmanes pasan por creyentes apasionados”. ${ }^{83}$ En Ceilán (la actual Sri Lanka) llega a una descripción cuasi teológica de los musulmanes: "Entre los musulmanes toda funcion física [...] fué suprimida, y Dios quedó reducido á un concepto metafísico, abstracto, y donde se deriva lógicamente el órden fatal". ${ }^{84}$ 
Ignacio Martínez también supedita el Islam a las culturas árabe y turca. Las palabras que dedica al Islam tienden a ser descripciones de cariz nacional, o "civilizatorio". Es decir, ya no se comprenden las cosas a la luz de la religión. Su visión es una visión secularizada. De entrada, cuando se aventura a visitar países menos convencionales para los viajeros profanos, asevera: "He visto los más de los países civilizados del globo, me decía á mí mismo, es preciso ahora recorrer los que me faltan, y sobre todo conocer las naciones que llaman semi-bárbaras". ${ }^{85}$

Su observación se acopla a las convenciones modernas, que juzgan el progreso o la decadencia de un país. Desde esa hermenéutica monopolizada, es fácil inferir que los países islámicos no son del todo agradables. Así se expresa cuando desembarca en Estambul:

Quiere la fatalidad que al tocarse la tierra, cese el encanto; que al cruzar las estrechas, sucias y lodosas callejuelas de esta capital, al pasar frente á sus hediondas barrancas y codearse con los haraposos y nauseabundos turcos, se desee que algo hubiese impedido el desembarco, para conservar la primera impresión. ${ }^{86}$

Sin embargo, Martínez no esgrime una estrecha causalidad entre el "nauseabundo turco" y su credo. De hecho, este viajero mitiga su juicio injurioso precisamente con alusiones al Islam:

Pero dejando á un lado lo inmundo de la ciudad, como en todo pueblo árabe ó turco, hay mil costumbres y objetos curiosos para el visitante. Los Derwiches danzantes y los chillones, la entrada del Sultán á la Mezquita, todos los Viernes, á hacer sus plegarias, obligando á los habitantes de las casas por donde pasa el cortejo á cerrar sus ventanas para no verlo. ${ }^{87}$

Algunas descripciones de corte puramente religioso delatan cierta animadversión, cuyo motor es el indisociable jacobinismo de su temperamento moderno. Se deja ver esto cuando Martínez viaja a la ciudad más religiosa del mundo: "Por lo demás, el amor á la fábula y á lo maravilloso, no es una condición especial de sólo los católicos, es de todas las sectas que habitan en Jerusalén”. ${ }^{88}$ Y, aun así, Martínez no sufre —como Guzmán— con los cantos árabes, sino que, incluso del habla cotidiana en Marruecos, dice: "El

Ídem.

${ }_{88}$ Ibíd., pp. 90-91. 
idioma que mi guía y él hablaban [el anfitrión que lo recibió], sin duda marroquí, era dulcísimo y puedo decir que más bien que conversación, me pareció un canto. Jamás he oído enunciar palabras tan musicales y melodiosas". ${ }^{89}$

Hay algo de onírico, repleto de beldades, en su viaje a "Oriente”. Nada impide que interprete las cosas que observa como las más sublimes bellezas. En su paso por Marruecos, Martínez no puede evitar caer enamorado de las mujeres con quienes se cruza. Según nos cuenta, en las calles de Tetuán una "mora” sin "antifaz" le lanzó miradas pícaras, lo que le convenció de ir tras sus pasos. Le intima a su lector:

Me iba forjando mil deliciosos ensueños con aquel casual hallazgo y aun me pareció fácil adorar el zancarrón de Mahoma y abrazar el Islamismo con tal de abrazar también aquella mujer tan hermosa; pero apenas había caminado unas tres cuadras, y en la vuelta de una esquina, se me perdió, sin que supiera yo en que casa había entrado. ${ }^{90}$

Martínez y Bulnes son dos observadores que, por su ontología más decantada a la consistencia moderna, pueden mirar las cosas en ánimo sesudo. Pueden percibir, pues, bondades y bellezas. Para ellos, en suma, las cosas son de facto muy diferentes que para los viajeros que les precedieron.

Uno de los relatos viajeros más leídos en su tiempo fue el Viaje á Oriente de Luis Malanco. Fue emprendido en 1876, y, a diferencia de Bulnes y Martínez, Malanco es moderado con inclinaciones al conservadurismo. En ese sentido, puede ponérsele en paralelo con López-Portillo, pues para Malanco, el "Oriente" es lugar, ante todo, de peregrinación. Aun se flagela a sí mismo por estar, cuando desembarca en Egipto, en un país de herejes. Cuando recibe una misiva en la que le notificaban que su hija, residente en Roma, había sido galardonada con la "medalla de la hija de María", Malanco escribe: “¡Pobrecita! mientras ella era elegida hija de María, en Roma, la ciudad que se dice mas creyente y la mas santa, yo andaba sobre una tierra que pertenecia á Mahoma y en Alejandría, la ciudad que se ha reputado mas fanática". ${ }^{91}$

A pesar de este evidente desprecio, el escrito — dividido en dos gruesos tomos - contiene abundantes descripciones de las costumbres que el viajero atestigua. Entre López-Portillo y Malanco se puede entablar un certamen para determinar quién representa con más vivacidad y mayor colorido el 
paisaje "oriental". Es necesario remitirnos al hecho de que el temperamento de ambos viajeros es una convergencia de las dos ontologías. Así, cabría explicar este copioso acervo de descripciones con la habilidad que ambos tienen de apreciar y despreciar simultáneamente a ese Otro ahí presente.

Sólo en ese término intermedio en el que procuran subsistir estos viajeros, sin resistencia a la Modernidad, dadas sus ventajas, y sin abandonar, tampoco, las ruinas del tridentinismo que todavía les da sentido, sólo ahí — decía - se pueden comprender las visiones de los viajeros de la sazón republicana. Cabe colocar en este estrecho, por ejemplo, las reflexiones que hace Luis Malanco sobre las mezquitas que en El Cairo visita:

La mezquita, es un medio entre los templos idólatras y las iglesias cristianas de este género [de un cristianismo "refinado"] [...]. En los templos paganos, hay ídolos deformes, oscuridad y pesantez; todo lo que sobrecoge, todo lo que asusta, todo lo que doblega al hombre por el miedo y el horror.

En los templos cristianos, hay ángeles, virtudes, luz, ligereza: todo lo que infunde esperanza, todo lo que inspira deseos, todo la [sic] que significa altísimos consuelos.

La mezquita musulmana, respira algo de materialismo y algo de espiritualidad, es un conjunto de ambos elementos, como es el islamismo la combinación hecha con ellos [...].

Las mezquitas del Cairo son magníficas: en el mundo sólo Roma con sus templos es capaz de comparársele. ${ }^{92}$

Quién puede negar que, en este ensayo de observación ecuánime, se asoman aún esos "resabios" tridentinos. Malanco, según cree, está plasmando sus pensamientos más objetivos. Pero su discurso no deja de oscilar entre la admiración por las mezquitas y la sobrevaloración del cristianismo —en menoscabo, obviamente, del Islam-. Inclusive hay que reparar con hincapié en el concurso arquitectónico que entabla entre Roma y El Cairo. La oscilación que presenta no es del todo contradictoria (rasgo que impondríamos a una barata periferia), sino que se asemeja bien al equilibrio habitual del funámbulo: necesita la feliz proporción en sus dos extremos para seguir adelante. Su compañero de viaje, José de Jesús Cuevas, forja en sus palabras la apoteosis de este funambulismo: "Mahoma, en el orden religioso, fué un impostor solemne". ${ }^{93}$

No tendría mayor provecho profundizar más en el Viaje á Oriente de Malanco. La ontología combinada a la que pertenece le permite interponer

93 Cuevas, "Discurso pronunciado en la Asamblea General de la Sociedad Católica de México, el 8 de Diciembre de 1872”, pp. 74. 
una distancia. Es decir, al paso que considera al musulmán como hereje, también admira la cultura islámica. Malanco no hace sino extrañarse del mundo que se le presenta. El musulmán es sumamente ajeno para la identidad de Malanco, y a ello responde que las interrogaciones, y sus soluciones, proliferen en su escrito.

Quizá por eso, en la correspondencia que mantiene con sus padres otro mexicano que viajó ese mismo año, Salvador Esquino, hay tanta congoja por no poder describir atinadamente ese mundo: "Estamos instalados en el Hotel de Europa, en el pequeño cuartel que llaman de los Estranjeros, y aparte de esto, que tiene cierto aire europeo, todo lo demás es tan raro y nuevo para mí, que al ménos por ahora no podría describírtelo: es el Oriente”. ${ }^{94}$ De la ciudad de El Cairo dice: "Nada hay en ella que se parezca á las nuestras". ${ }^{95}$ Se debe concluir, ante esta novedad, que el musulmán adquiere alteridad. Y es que, ni para la ontolgía tridentina, ni para la moderna, el musulmán es un ente extraño. Ambas ontologías encuentran la manera de instrumentar sus propias categorías para aprehender a esos musulmanes. Por un lado, la ontología tridentina tiene una realidad constituida por cristianos y cristianos en potencia. ${ }^{96}$ Así lo estatuyó san Pablo: "No hay distinción entre judío y gentil. Uno mismo es el Señor de todos” (Rom 10, 12). Por su parte, la ontología moderna acoge a todos los humanos como constituyentes del universo, en suma, como iguales.

Es así que llegamos a los dos últimos relatos viajeros a estudiar. A éstos no queda más que motejarlos como intempestivos, como obras empecinadas en los tiempos perdidos. Pues se trata de dos relatos de peregrinaciones conformadas por la ortodoxia católica más recalcitrante de su momento. Es importante decir que una actitud de parejo ensimismamiento sólo es posible cuando se instaura la tregua, el final de las hostilidades, entre el Estado y la Iglesia. Esto sólo acontece en el momento en que Porfirio Díaz sube al poder, entre cuyos adagios implícitos descuella aquel que reza: "Liberales en la letra, conservadores en la práctica". ${ }^{97}$ Huelga recordar que esta tregua con el catolicismo lleva a la ontología tridentina a fijarse como una realidad latente en la historia de México.

Impresiones religiosas de un viaje a Tierra Santa, del presbítero zacatecano José María Portugal, es una resonancia remota de los primeros relatos de peregrinación. La diferencia evidente es que las injurias y las palabras de vejación contra los musulmanes ya no parecen tener demasiada vigencia en 
ese 1886 mexicano. Portugal, sin embargo, no omite ni una tilde cuando se trata de despotricar contra el hereje.

Los turcos, siempre desaceados y de aspecto repugnante. Las mujeres turcas tambien, andan con vestidos ridículos: la cara á medio cubrir, y todas ellas feas y asquerosas. [...] Á más de los turcos hay en Alejandría, muchos griegos, armenios, coptos y europeos. En cuanto á los últimos muchos vienen por el comercio, otros por vivir á lo musulman, y los demas son el desecho de Europa. - Con tales elementos, no es difícil calcular, cuál será con el tiempo el progreso de esta ciudad. ${ }^{98}$

El siglo XIX de viajeros al "Oriente" culmina con el viaje de veintiséis o veintisiete religiosos mexicanos $-\mathrm{y}$ sus familiares-. Esta peregrinación toma un carácter oficial, pues lo auspicia la Iglesia católica, y sus andares se divulgan en los periódicos. Esta peregrinación multitudinaria tiene más de dos relatos como fuentes históricas. Por un lado, están los tres tomos de José Trinidad Basurto, Recuerdo de mi viaje, ${ }^{99}$ y el más breve Cartas y ligeros apuntes de un viaje a Roma y Tierra Santa, de su tío Modesto Basurto, quien recopila las notas que publicó en El Tiempo.

Tanto Portugal como Trinidad Basurto comparten un lenguaje en común: "nos divertíamos [...] sentados viendo á tantos árabes, tan feos, tan sucios y tan flojos, sentados en unas sillas de tantos cafés como hay en esta ciudad de cincuenta mil habitantes y entre ellos muchísimos europeos, á quienes deben en gran parte la poca civilización que puedan tener”. ${ }^{100}$

Hay mucho más material, sumamente ofensivo, que no serviría añadir aquí. Vemos que los dos últimos relatos, escritos en el México porfiriano, están repletos de groseros calificativos en contra de los musulmanes. Lo cual se explica por la confianza en la que ya pueden desarrollarse los religiosos en México, cuando su confesión deja de ser perseguida. Pero también cabe destacar que, a diferencia de los primeros peregrinos (Guzmán y Camacho), Portugal y Basurto presentan una mayor cantidad de juicios negativos. Esto sólo es posible después de que la ontología moderna desarrollara la capacidad, entre sus vástagos, de observar con detenimiento al "humano incivilizado". Estamos, así, ante una ontología tridentina valetudinaria que no puede rechazar ya - y que de hecho contiene en su senola ontología moderna.

Portugal, Impresiones religiosas de un viaje a Tierra Santa, pasando por Nueva York, Paris y algunas ciudades de Italia, por el R. P. Fr. José María Portugal, p. 176.

99 Cfr. supra. nota 14.

${ }^{100}$ Basurto, op. cit., I, pp. 36-37. 


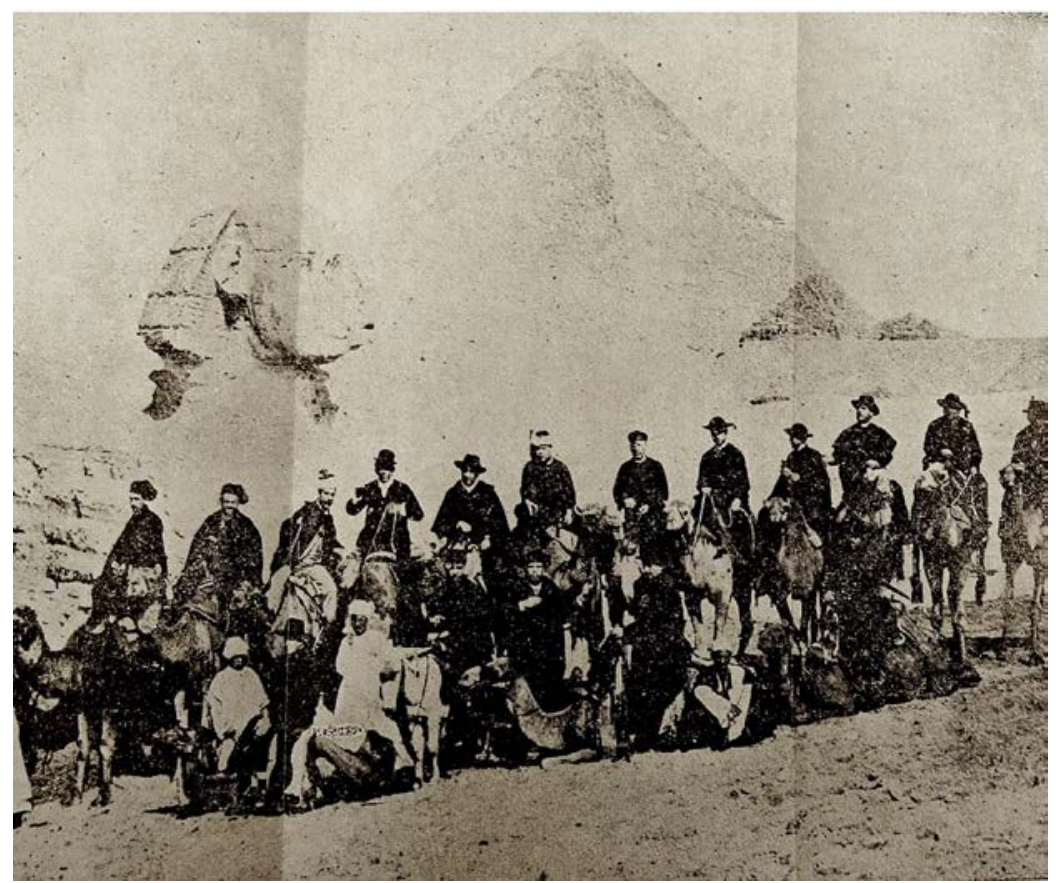

Imagen 2. Un fotógrafo acompañaba a los casi treinta peregrinos que viajaron a Egipto y Palestina en 1898 (relatado por los presbíteros Basurto). A pesar de la mala contextura, la fotografía captura el gesto beato de un sacerdote no identificado. Él, en la fila inferior al costado izquierdo de un egipcio, no monta en camello, sino que, sobre un burro blanco, reactualiza — casi eucarísticamente — la «Huida a Egipto» de la Sagrada Familia cuando ésta sale, según la Tradición de Mateo 2:13-23, en lomos de un asno, de la Judea de Herodes. Vemos, aquí, a esos viajeros mexicanos con dos lógicas combinadas: son viajeros que insisten en peregrinar, a la usanza tridentina, pero que, a su vez, viven en tiempos de Modernidad porfiriana, para la cual la fotografía fue un elemento imprescindible.

Finalmente, hay que subrayar algo más. La peregrinación de Basurto es bien emblemática porque se honra, a sí misma, como la Primera Peregrinación Mexicana a Tierra Santa. ¿Qué pasó con las peregrinaciones anteriores? ¿No era igual de importante la peregrinación de Camacho, acompañado por el jerarca exiliado (Labastida)? ¿No es esto, acaso, signo de que el viaje beato dejó de ser un hecho ordinario (ontológico) y devino, así, un fenómeno insólito, digno de rememorarse como se rememoraría un acto cívico? He ahí 
cómo el universo tridentino se funde con la Modernidad en ese cierre del siglo XIX, para dar lugar al catolicismo mexicano del siglo XX.

\section{CONCLUSIÓN}

En nuestro presente, el Islam es una fuente incesante de controversias. En medios divulgadores de información, y en las socorridas redes sociales rebosan las representaciones de los musulmanes. El surgimiento de extremismos islámicos es la principal causa de la presencia de cuestiones islámicas en la comunicación masiva. Y la consecuencia inevitable de este hecho es la factura de una imagen distorsionada de los musulmanes y de la fe islámica. En nuestra época se ha maniobrado, así, un temor generalizado sobre los musulmanes, al que se ha denominado islamofobia. Ésta es una tendencia preponderante entre las personas que viven en Occidente, especialmente en países donde fluye la migración de países con credos mayoritariamente musulmanes. Sin embargo, hay un paulatino reconocimiento de los efectos negativos que tiene el prejuicio islamófobo por parte de algunos sectores de la población occidental. Así, hoy se puede percibir una notable escisión entre los islamófobos y los defensores de que el Islam no es reducible al fenómeno del terrorismo. A estos últimos se les ha denominado islamófilos. ${ }^{101}$

México no es una nación inmune a la escisión entre islamófobos e islamófilos. Y aunque la presencia de musulmanes sigue contándose en minorías, circula, también, mucha información tendenciosa sobre los musulmanes. La presencia del Islam en México ha sido históricamente restringida, hasta esta época de globalización. Hoy existen poblaciones de naciones extranjeras que cambian el panorama cultural de México. La respuesta de los mexicanos frente a este importante cambio ha sido, regularmente, negativa. Por hablar de los musulmanes - extranjeros y mexicanos - es altamente recurrente encontrar notas acerca de persecución religiosa (especialmente en el sur de México). Una explicación de por qué existe esta recepción violenta de los musulmanes en México merece ser tratada con urgencia.

Este estudio puede contribuir a ese porqué. En estas páginas se ha analizado una cadena de opiniones, vertidas por los mexicanos del siglo XIX, sobre los musulmanes. La pregunta desarrollada aquí involucra la representación que los mexicanos ejecutaban de los musulmanes. Un análisis cuidadoso de las maneras de representar a los musulmanes por parte de los mexicanos, en las distintas etapas de la historia, no podrá menos de notar la fuerza ejercida

101 Un documento muy informativo al respecto es "Islamophobia: Understanding Anti-Muslim Sentiment in the West”, consultable en <https://news.gallup.com/poll/157082/islamophobiaunderstanding-anti-muslim-sentiment-west.aspx $>$. 
por la lógica de la religión católica romana. Ya existe una considerable cantidad de investigaciones sobre los musulmanes en, y durante, el virreinato novohispano. El eje sobre el cual giran esos estudios es, naturalmente, la documentación del Santo Oficio de la Inquisición. Ahí despuntan unos cuantos casos de acusaciones de probables herejes que coqueteaban con creencias "moriscas" y "mahometanas". A esto hay que añadir la constante existencia de discursos anti-islámicos, procedentes de la visión peninsular, como la figura de Santiago Matamoros, o del rey católico que reconquista los reinos musulmanes. A pesar, pues, de que la presencia de musulmanes en el virreinato era limitada, la carga de representaciones mentales sobre ellos es flagrante.

Paralelas a las investigaciones novohispanistas, existe también mucha indagación sobre los árabes y los turcos que salieron del Imperio Otomano, y llegaron a México en la aurora del siglo Xx. El objeto de indagación se centra, sobre todo, en las andanzas y las peripecias de las poblaciones sirio-libanesas en México. Sin embargo, hay limitadas relaciones entre estas peculiares migraciones y la fe islámica porque numerosos migrantes profesaban la religión católica de rito maronita. Es por eso que los conflictos entre mexicanos y árabes, acontecidos en el seno de la inmigración, se estudia desde el ángulo de la nacionalidad, y no tanto desde el de la religión. Ya se sabe, de hecho, que un punto de coexistencia entre los mexicanos y estos inmigrantes fue la religión. A tal grado resultó esta armonía, que fecundó en México una devoción mutua con enorme vehemencia: la del santo Charbel Makhlouf (شربل مخلوف).

Así pues, decía ya que los estudiosos de la cuestión musulmana en México no pueden desatender los mecanismos hermenéuticos del catolicismo romano. Éste ha configurado la manera de interpretar a los musulmanes en México. Entre los dos extremos de esta historia (por un lado, el del virreinato novohispano y, por el otro, el de la inmigración de inicios del siglo Xx) se localiza el estudio aquí tratado. Vemos que hay, en el extremo novohispano, una idea heresiológica y teológica de los musulmanes. Es una visión arraigada en la historia del catolicismo romano, al menos, desde tiempos de Carlo Magno o del emperador bizantino Heraclio, pero revigorizada por el catolicismo contrarreformista (el catolicismo tridentino). Vemos, en el otro extremo, a unos mexicanos que reciben con suspicacia a los inmigrantes turcos y árabes, pero que pueden coexistir con ellos y eventualmente acogerlos. El punto intermedio entre ambos extremos es el siglo XIX, que no es sino el siglo del conflicto entre Modernidad y Tradición. Este conflicto definió a tal grado el curso de la historia mexicana que también condicionó la representación que los mexicanos se hicieron de los musulmanes. 
Los viajeros mexicanos que visitaron el Medio Oriente, durante el siglo XIX, son síntomas de su propia circunstancia histórica. En este estudio, se pudo apreciar que aquéllos que hicieron la travesía, en la primera mitad del siglo XIX, fueron peregrinos. Un mexicano de esa época, los primeros años de nación independiente, aún tenía una mentalidad propia del virreinato; era una lógica tridentina. En esta mentalidad, no existe como tal el viaje turístico al Oriente, sino sólo peregrinajes a la Tierra Santa. Esta hermenéutica tridentina sólo pudo interpretar a los musulmanes como herejes, y así lo demuestran las opiniones del padre José María Guzmán y el padre Rafael Sabás Camacho.

La segunda mitad del siglo XIX supone una ruptura. Ya hay mexicanos que no se identifican ni con su pasado hispánico, ni con un probable gobierno monárquico, ni, inclusive, con el catolicismo tridentino. Son mexicanos de la Modernidad. Ellos inauguran el viaje turístico al Medio Oriente. Ellos viajan para conocer, para saciar la curiosidad, para aprender, ya no para peregrinar. Aquellos viajeros mexicanos plenamente modernos, que delatan su propia lógica en su contemplación de los musulmanes, tienen a sus mejores dechados en el general Ignacio Martínez y en Francisco Bulnes. El elemento teológico desaparece absolutamente, pero predominan los calificativos civilizatorios, que inevitablemente infravaloran a los "turcos" y "árabes".

No obstante, esta separación entre peregrinos y turistas son dos extremos, y la historia no puede estudiarse desde los extremos. En este estudio salió a la luz un género muy peculiar de viajeros mexicanos. Se trata de aquéllos que conjuntan, en su individualidad, los rasgos tridentinos y los rasgos modernos. Son ellos viajeros-peregrinos. Mientras que el peregrino mexicano despotrica en contra del musulmán, por interpretarlo como hereje, y mientras que el turista mexicano lo estudia culturalmente (y, a menudo, lo desprecia por no ser occidental), el viajero-peregrino lo interpreta como un hereje culturalmente interesante. Ejemplos de viajeros-peregrinos son el escritor José López-Portillo y Rojas, el delegado mexicano en Italia, Luis Malanco, Salvador Esquino, y aún los recalcitrantes José María Portugal y José Trinidad Basurto.

Es este término medio, de mexicanos que simultáneamente absorben su catolicismo y su modernidad, el que caracteriza a los viajeros mexicanos del siglo XIX. Ellos son el producto innegable del conflicto entre Modernidad y Tradición, en el siglo XIX mexicano. El viajero-peregrino mexicano explica, muy elocuentemente, cómo se formó al musulmán, entre el virreinato novohispano y el siglo XX, para los mexicanos. Y ayuda a explicar, asimismo, la recepción que dan hoy los mexicanos a los musulmanes en pleno siglo XXI. 


\section{BIBLIOGRAFÍA}

Aguilar, Adrián Guillermo (coord.), Las grandes aglomeraciones y su periferia regional. Experiencias en Latinoamérica y España, México, Cámara de Diputados/UnAm/Conacyt/Porrúa, 2006.

Aguilar, José Antonio y Rafael Rojas (coords.), El Republicanismo en Hispanoamérica. Ensayos de historia intelectual y política, México, Fondo de Cultura Económica/CIDE, 2014 (2002).

Arango Miranda, Azucena, "Los conjuntos habitacionales como agente de densificación masiva de periferia en la ciudad de México: Ixtapaluca”, en Enrique Soto y Héctor Padilla (coords.), Memoria del Congreso Nacional de Vivienda 2013. 12, 13 y 14 de marzo. Eje Temático 9: Desarrollo urbano y grandes conjuntos habitacionales, México, UNAM, 2013.

Bartra Vega, Armando, Rosario Cobo y Lorena Paz, La hora del café. Dos siglos a muchas voces, México, Comisión Nacional para el Conocimiento y Uso de la Biodiversidad, 2013.

Basurto, José Trinidad, Recuerdo de mi viaje. Historia de la segunda peregrinacion mejicana a Roma y primera a Tierra Santa. Abraza todas las noticias que tienen relacion con la excursion iniciada y llevada a feliz término por el Apostolado de la Cruz desde la salida de la capital hasta la funcion que para secundar el deseo de ntro. smo. padre el Señor Leon XIII tuvo lugar el la Colegiata de Guadalupe, Méjico, Tipografía de "El Tiempo", cerca de Santo Domingo, No. 4, 1898.

Bergel, Martín, El Oriente desplazado: Los intelectuales y los orígenes del tercermundismo en la Argentina, Bernal, Universidad Nacional de Quilmes, 2015.

Biblioteca Nacional de España, Libros de viajes y viajeros de los siglos XVI-XIX, España, 2016, p. 2, disponible en <http://www.bne.es/es/Micrositios/Guias/Viajes/resources/docs/Guia_Libros _de_de_viaje_y_viajeros_Siglos_XVI-XIX.pdf>

Bulnes, Francisco, Sobre el Hemisferio Norte. Once mil leguas. Impresiones de viaje a Cuba, los Estados Unidos, el Japon, China, Cochinchina, Egipto y Europa, por Francisco Bulnes, Historiógrafo de la Comisión Mexicana enviada al Japon por el Supremo Gobierno para observar el tránsito de Vénus por el disco del Sol, México, Imprenta de la Revista Universal, Primera calle de San Francisco núm. 13, 1875.

Camacho, Rafael S., Itinerario de Roma á Jerusalén escrito el año de 1862, Guadalajara, Tipografía de Dionisio Rodríguez, 1873.

Centeno, Amaro, Historia de cosas del Oriente. Contiene una descripcion general de los Reynos de Assia con las cosas mas notables dellos. La Historia de los Tartaros y su Origen y principio. Las cosas del Reyno de Egipto. La Historia y sucesos del Reyno de Hierusalem, Primera y Segunda parte, Impresso en Cordova en casa de Diego Galvan, 1595. 
Chávez Jiménez, Daniar, "Viajeros del siglo XIx: el linaje mexicano y las 11 mil leguas de Francisco Bulnes por el Hemisferio Norte”, en Estudios, 108, vol. XII, 2014, pp. 53-72.

Chinchilla Pawling, Perla, "Las 'formas discursivas'. Una propuesta metodológica”, Historia y Grafía, México, Universidad Iberoamericana, año 22, núm. 43, 2014, pp. 15-40.

Couto, José Bernardo, "Biografía de Don Manuel Carpio”, en Manuel Carpio, Poesías, México, Imprenta de Andrade y Escalante, 1860.

Cuesta, Fray Vicente, Viaje a la Tierra Santa en el Año del Señor de 1870. Nueva edición de sus cartas, Popayan, Imprenta del Estado, 1873.

Cuevas, José de Jesús, Obras. Tomo I. Discursos Religiosos, México, Imp. de V Agüeros Editor, 1898.

De Hamme, Lièvin, Guide-indicateur des sanctuaires et lieux historiques de la Terre-Sainte, Revue, augmentée et accompagnée de cartes, de plans et de vues. Première Partie, Jérusalem, Imprimerie des PP. Franciscains, Troisième Édition, 1887.

Echeverría, Bolívar, La Modernidad de lo barroco, México, Ediciones Era, 2000.

Elias, Norbert, El proceso de la civilización. Investigaciones sociogenéticas y psicogenéticas, trad. Ramón García, Madrid, FCE, 1987.

Galván Rivera, Mariano, La tierra santa ó descripción exacta de Joppe, Nazareth, Belem, el Monte de los Olivos, Jerusalén y otros lugares célebres en el evangelio, a lo que se agregan una noticia sobre otros sitios notables del pueblo hebreo, México, Librería de Recio y Altamirano, 1842.

García, C.M.F., Pedro, El Padre Plancarte: figura prócer de la Iglesia católica mexicana, México, Hijas de María Inmaculada de Guadalupe, 2007.

García Ugarte, Marta Eugenia, Poder político y religioso. México siglo XIX, tomo I, México, Cámara de Diputados/unAm/IMDOsoc/Porrúa, 2010.

González Navarro, Moisés, Los extranjeros en México y los mexicanos en el extranjero, 1821-1970: Tomo 2, 1867-1910, México, El Colegio de México, 1994.

Guzmán, José María, Breve y sencilla narracion del viage que hizo a visitar los santos lugares de Jerusalén el P. Fr. Jose Maria Guzman, Americano, hijo del Colegio Apostólico de nuestra Señora de Guadalupe de Zacatecas en la República Mexicana: quien la dedica á su patria. Publícala un amigo del autor, México, Imprenta de Luis Abadiano y Valdés, 1846.

Hanıoğlu, Şükrü M., A Brief History of Late Ottoman Empire, USA, Princeton University Press, 2008.

Hugo, Victor, Quatrevingt-treize, France, Le Livre de Poche, 2001.

Kahat, Farid y José Alberto Moreno, "La inmigración árabe hacia México (18801950)”, en Abdeluahed Akmir (coord.), Los árabes en América Latina. Historia de una emigración, España, Siglo XXI/Casa Árabe e Instituto Internacional de Estudios Árabes y del Mundo Musulmán, 2009. 
Koselleck, Reinhart, Futures Past: On the Semantics of Historical Time, New York, Columbia University Press, 2004.

_- Vergangene Zukunft. Zur Semantik geschichtlicher Zeiten, Frankfurt am Main, Suhrkamp, 1995.

Lamartine, Alphonse de, Harmonies poétiques et religieuses, Paris, Charles Gosselin, Furne et Cie., Pagnerre, 1847.

Lemmons, Russel, “'If there is a hell, then Rome stands upon it': Martin Luther as Traveler and Translator”, in Carmin G. Di Biase (ed.), Travel and Translation in the Early Modern Period, Amsterdam, Rodopi, 2006, pp. 33-44.

López-Portillo y Rojas, José, Egipto y Palestina: apuntes de un viaje. Libro I: Egipto, México, Díaz de León y White, 1874.

— Egipto y Palestina: apuntes de un viaje. Libro II: Palestina, México, Díaz de León y White, 1874.

Lugo, Joannis de, Opera Omnia, Tomus Tertius. Cum indicibus necessariis, Venetiis, 1718.

Mac Gregor, Josefina, Del Porfiriato a la Revolución: Antología, México, El Colegio de México, 2015.

Malanco, Luis, Viaje á Oriente, Tomo Primero, México, Imprenta AgrícolaComercial, Calle de Arsinas núm. II, 1882.

Maravall, José Antonio, Culture of the Baroque. Analysis of a Historical Structure, tr. by Terry Cochran, Minneapolis, University of Minnesota Press, 1986.

Martínez, Ignacio, Recuerdos de un viaje en América, Europa y África, por Ignacio Martínez, Doctor en Medicina y General de la República Mexicana. Obra ilustrada con 354 grabados y un mapa, París, Librería de P. Brégi, 37 bis, Rue des Saints-Pères, 37 bis., 1884.

. Viaje Universal. Visita a las cinco partes del mundo. Acompañado de un Mapa Ilustrativo y con un prólogo del distinguido literato General Vicente Riva Palacio, Nueva York, José S. Molins, 1886.

Mohssine, Assia, "El relato de viaje de José María Guzmán por Oriente (1837). Entre construcción identitaria y palabra panfletaria”, en Cuadernos del CILHA, vol. 13, núm. 1, julio 2012, pp. 65-79.

O’Gorman, Edmundo, La supervivencia política Novo-hispana. Monarquía o República. Reflexiones sobre el monarquismo mexicano, México, Universidad Iberoamericana, 1986 (1967).

Ortega y Gasset, José, El Espectador, Tomo VI (1930), en Obras Completas, Tomo II, Madrid, Revista de Occidente, Sexta Edición, 1963.

Rodríguez O., Jaime E., “Nosotros somos ahora los verdaderos españoles”. La transición de Nueva España de reino de la Monarquía Española a la República Federal de México, 1808-1824, Zamora/Distrito Federal, El Colegio de Michoacán/Instituto Mora, 2009.

- The Independence of Spanish America, New York, Cambridge University Press, 1998. 
Romero, Matías, “Tercera parte. Apéndice. Artículos sobre el cultivo del café en varios Distritos de México y en Alta California”, en El Estado de Oaxaca, Barcelona, Tip.-Litogr. de Espasa y comp., 1886.

Said, Edward W., Orientalism, New York, Vintage Books, 1979.

Salinas Quiroga, Genaro, Historia de la cultura nuevoleonesa, Monterrey, Universidad Autónoma de Nuevo León, 1981.

Schopenhauer, Arthur, Aphorismen zur Lebensweinsheit, Im Insel-Verlag zu Leipzig, 1917.

Taboada, Hernán G.H., “Un orientalismo periférico; viajeros latinoamericanos, 17861920”, en Estudios de Asia y África, vol. 33, núm. 2, 1998.

Teixidor, Felipe, Viajeros Mexicanos (siglos XIX y XX), México, Editorial Porrúa, 1939.

Tinajero, Araceli, Orientalismo en el modernismo hispanoamericano, Indiana, Purdue University Press, 2004.

Tornel, José María, “Bibliografía: México, ó las Memorias de un viajero: por Isidoro Lowenstern, autor de: "Los Estados Unidos y la Habana”. Un tomo en $4^{\circ}$, en frances, impreso en Paris por Arturo Bertrand”, en El museo mexicano: ó Miscelánea pintoresca de amenidades curiosas é instructivas, tomo II, México, I. Cumplido, pp. 241-255.

Tyutina, Svetlana V., "Hispanic Orientalism: The Literary Development of a Cultural Paradigm, from Medieval Spain to Modern Latin America”, in FIU Electronic Theses and Dissertations, no. 1592, Miami, Florida International University, 2014.

Vogel, Cyrille, “Le pèlerinage pénitentiel”, en Revue des Sciences Religieuses, tome 38, fascicule 2, 1964, pp. 113-154.

Weber, Max, La ética protestante y el espíritu del capitalismo, Edición de Jorge Navarro Pérez, Madrid, Akal, 2015 (1998).

Woestmann, O.M.I., William H., “Mexico-Opportunity Turned Down”, in Vie Oblate Life, vol. 54, Ottawa.

Yeager, Suzanne M., Jerusalem in Medieval Narrative, USA, Cambridge University Press, 2008. 